\title{
THE BITTER CRY OF OUTCAST LONDON
}

In the autumn of 1883 a small, anonymous penny pamphlet bearing the provocative title The Bitter Cry of Outcast London appeared in the London bookstores. Its impact was so immediate and cataclysmic that it must be considered one of the great pieces of Victorian reform literature. ${ }^{1}$ According to contemporary opinion the pamphlet provoked an "immense interest" 2 in and "drew attention universally to the subject" 3 of the dwellings of the working classes, and by the winter of 1883 it was unanimously agreed that urban slum conditions had "assumed the dimensions of a primary question" and had become "the subject of the day". "Alfred Spender, the editor of the Westminster Gazette, stated in 1913 that it was almost impossible to recapture "the sensation which such a pamphlet as 'The Bitter Cry of Outcast London' made when it was first produced.". Suddenly, almost overnight, it seemed, England awoke to the grim facts of the slums. "The revelations concerning 'Outcast London", commented Reynolds Newspaper, "cause a tremendous sensation and thrill of horror through the land ..."6 In January 1884 the Pall Mall Gazette wrote that The Bitter Cry had been

1 Yet, strangely, this pamphlet has received little attention from historians. Both W. Ashworth, The Genesis of Modern British Town Planning (London, 1954) and H. Barnes, The Slum. Its Story and Solution (London, 1931) ignore The Bitter Cry. Mrs H. Lynd mentions it in her England in the Eighteen Eighties (London, 1954), and K. Inglis makes excellent use of it in his Churches and the Working Classes in Victorian England (London, 1963).

2 The Malthusian, No 57, December, 1883.

3 Parliamentary Papers, 30 (1884-5), Royal Commission on the Housing of the Working Classes. II. Minutes of Evidence, p. 103. Hereafter I will refer to this source as PP, 30 (1884-5), RCHWC II. RCHWC I will refer to the First Report of the Commission.

4 Daily Telegraph, November 26, 1883, and ibid., October 31, 1883. Lancet on December 1, 1883 wrote, "The housing of the poor is the burning question of the hour" (p. 961).

5 Quoted in H. Barnett, Canon Barnett. His Life, Works, and Friends (London, 1919), p. 309.

6 Reynolds Newspaper, October 28, 1883. 
echoing from one end of England to the other, and commented, "We shall have to go back a long time to discover an agitation on any social question in England which has produced so prompt, so widespread, and, as we believe, so enduring an effect." 1 Two years after its publication it was reported that The Bitter Cry "rang through the length and breadth of the land. It touched the hearts of tens of thousands, and awoke deep feelings of indignation, pain, and sympathy in every direction."' 2 The agitation stimulated by The Bitter Cry was not short-lived or fruitless, for it forced both parties to pay attention to housing conditions in working class districts, and led directly to the appointment of a royal commission on the housing of the working classes. The new concern over the nation's slums did not die down until it had penetrated the walls of Buckingham Palace, new housing legislation had been passed, and the clearance of London's slums and the re-housing of the evicted entrusted to a new, infinitely stronger municipal government.

From the immediate reception of The Bitter Cry, the horror and indignation it provoked, and the intense and widespread reform movement it aroused, it might be assumed that it was the first exposé of slum life available to the Victorian general public and that until its appearance the London slums were a terra incognita. Several years after its publication the Pall Mall Gazette stated, with an exaggeration that reveals the impact of the pamphlet upon contemporaries, that "it was not until the 'Bitter Cry' stirred the nation that the slums came to be regarded as unpleasant abodes ...."3 Yet the fact is that The Bitter Cry was just one of many articles and pamphlets of the time on working class housing and followed upon scores of descriptions, both sober and sensational, of the slums of the metropolis. Indeed, three years before the appearance of The Bitter Cry the author of a housing reform tract felt obliged to apologise for writing on the subject. The living conditions of the poorer classes had been so frequently described, he wrote, "that it appears superfluous at the present time to enlarge upon it, or to enter into distressing details now so widely known and so deeply deplored."

Throughout the nineteenth century there was a stream, though by

1 Pall Mall Gazette, January 2, 1884, in a leader "The First Fruits of the "Bitter Cry" ".

" "Light and Shade". Pictures of London Life. A Sequel to "The Bitter Cry of Outcast London" (London, 1885), p. 1.

- Pall Mall Gazette, February 15, 1889.

- F. Rivington, A New Proposal for Providing Improved Dwellings for the Poor., (London, 1880), p. 1. 
no means a constant one, of writings on working class living conditions. ${ }^{1}$ Before 1880 much of it was in the vein of popular journalism or of travelogue literature and tended to portray the quaint and picturesque rather than analyze the extent and causes of the miserable conditions in which so many of the poor were living. This social reportage, which was often linked to popular journalism and the desire to paint London as a place of deep mysteries and sensational wickedness, rarely progressed beyond a description of the crooked streets and dark courts and alleys into the rooms of the poor. Typical of such writing was Henry Mayhew's famous multi-volume London Labour and the London Poor: $A$ Cyclopaedia of the Conditions and Earnings of Those That Will Work, Those that Cannot Work, and Those that Will Not Work (1861-62), which first appeared in the Morning Chronicle in 1849 and 1850, and which "For all their definition, colour, and humanity, ... provided little more than a panorama of the poverty - and of the intinerant employment - to be seen on the streets". 2 The descriptions of the slums contained in the writings of Mayhew, Dickens (especially in his journals, Household Words and All the Year Round), ${ }^{3}$ Kingsley, ${ }^{4}$ Bosanquet, ${ }^{5}$ Jerrold, ${ }^{6}$ Sala, ${ }^{7}$ and Greenwood, ${ }^{8}$ though they said little about the interior arrangements in the houses, did focus upon sanitary evils and did much to draw attention to the plight of the poor. In

1 For a bibliography of this material with an excellent critical summary see H. J. Dyos, "The Slums of Victorian London", in: Victorian Studies, XI, No 1 (September, 1967). See also: R. Glass, "Urban Sociology in Great Britain. A Trend Report", in: Current Sociology, IV, No 4 (1955).

2 Dyos, p. 12.

3 See the titles in Dickens' periodicals listed in Dyos, p. 16. In addition see Household Words, May 25, 1850, p. 199; ibid., June 22, 1850, p. 297. Typical of the rather romantic treatment is "Down Whitechapel Way" (ibid., November 1, 1851, pp. 126ff.), where everything, however disagreeable, is picturesque, and where all is enchanting noise and bustle.

- Kingsley was extremely active in sanitary reform, and wrote several tracts pointing out the dangers of permitting the lower classes to live in unsanitary houses. See his Miscellanies, 2 vols (London, 1860).

- C. B.P. Bosanquet, London: Some Account of its Growth, Charitable Agencies and Wants (London, 1868).

- D. Jerrold, St. Giles and St. James (London, 1851).

7 G.A. Sala, Twice Round the Clock; or, The Hours of the Day and Night in London (London, 1859); Gaslight and Daylight, with some London Scenes they Shine Upon (London, 1860).

8 J. Greenwood's principal interest and purpose may be gathered from his titles among which are: The Wilds of London (London, 1874), The Seven Curses of London (London, 1869), Unsentimental Journeys; or, Byways of the Modern Babylon (London, 1867), Low Life Deeps; an Account of the Strange Fish to be Found There (London, 1876), Odd People in Odd Places, or the Great Residuum (London, 1883). 
addition to these popular works, the investigations of the poor law commissioners threw light upon the slums, as did Chadwick's Report on the Sanitary Condition of the Labouring Population (1842), the report of the Commission on the State of Large Towns and Populous Districts (1844), the works published by the Health of Towns Association (founded in 1844), and the reports of the Metropolitan Sanitary Commission. ${ }^{1}$ The public health movement which Chadwick headed, and which culminated in the Public Health Act of 1848, produced so many works on the sanitary state of the large towns that one housing reformer could declare in 1851 that "to speak of the evils of bad drainage, the insufficient ventilation, and the dilapidated condition of the back streets, courts, and alleys of London, is almost superfluous; they have been denounced in every form of letter, leading article and harangue."2 But his use of language is revealing, for up to 1880 the housing of the working classes was but part of the much broader social problem of public health. Sewers, drains, street cleaning, cesspools, cemeteries, water supply, all occupied more public attention, and were better described and therefore better known than the interior domestic arrangements of the poor. Until the revelations of the early 1880 s few writers bothered to take their readers out of the slum streets and into the houses of the working classes.

Of course there were notable exceptions. The Builder, under the editorship of the active housing reformer George Godwin, devoted much space to conditions within the houses of the urban working classes and was one of the first journals to point out the dangers of over-

1 Chadwick's report sold in great quantities and was widely read. For a critique of it see the introduction to M. W. Flinn, ed., Report on the Sanitary Condition of the Labouring Population of Great Britain, by Edwin Chadwick. 1842 (Edinburgh, 1965). The Metropolitan Sanitary Commission was appointed to devise ways of combating the cholera epidemic, which appeared in Europe in 1847, and revived memories of the awful visitation of 1832 . Under the guidance of Chadwick the Commission painted lurid pictures of the squalor and disease-breeding filth of working class districts.

2 A Brief Inquiry into the Evils attendant upon the Present Method of erecting, purchasing, and renting Dwellings for the Industrial Classes, etc. (London, 1851) pp. 7-8. For a similar statement see R. H. Cheney, "The Missing Link and the London Poor", in: The Quarterly Review, CCXV (July 1860). Cheney actually described the problem most accurately: "Everywhere the root of the evil is the excess of demand above supply. The philanthropist must never forget that it is more urgent to multiply the dwellings of the poor even than to improve them. Overcrowding would turn a Paradise into a 'rookery' and a palace into a 'den'." (p. 3) It is interesting to note that Dickens still regarded Whitechapel, Ratcliff, Shadwell, Poplar, Limehouse, and Rotherhithe as terrae incognitae. See Household Words, November 1, 1851, p. 126. 
crowding. ${ }^{1}$ More analytical and quantitative in nature were the many penetrating and accurate papers which were read at the meetings of the Statistical Society of London and published in the Society's journal. These papers covered many parts of working class London and provide a most valuable picture of working class housing conditions, especially in the 1840 s. $^{2}$

The Journal of the Statistical Society of London described the dwellings of both the "criminal" and the "respectable" poor, and brought to the attention of its readers both the worst and what it considered to be the average housing conditions prevailing in working class London. In 1845, for example, the Council of the Society became concerned with the fact that nearly all contemporary descriptions of London were confined to the very worst districts, and in the summer of that year a committee of the Society set out to accumulate evidence of the average living conditions of London's regularly employed artisan (that is skilled and semiskilled) and labouring classes. ${ }^{3}$ The committee decided to investigate St. George-in-the-East (the parish was later part of Stepney Borough in East London), and its painstaking inquiry, in many respects unsurpassed until the monumental studies forty years later by Charles Booth, was published in the Journal of the Society in 1848. The committee found the area to be composed of

"dingy streets, of houses of small dimensions and moderate elevation, very closely packed in ill -ventilated streets and courts, such as are commonly inhabited by the working classes of the east end; and, indeed, it may be said, of all parts of London, beyond the limits of that congested band around its centre, where overcrowding is carried to the greatest excess."4

It was a district where the number of native-born Londoners was about equal to the number of immigrants. The committee had chosen St. George-in-the-East because its inhabitants, who were gunsmiths, coopers, porters, carmen, bakers, shoemakers, bricklayers, carpenters,

1 See G. Godwin, London Shadows (London, 1854), Town Swamps and Social Bridges (London, 1859), and Another Blow for Life (London, 1864). For other critical works see Rev. T. Beame, The Rookeries of London: Past, Present, and Perspective (London, 1851), and H. Gavin, Sanitary Ramblings (London, 1848). 2 These papers are too numerous to list here but see the Journal of the Statistical Society of London: I (1839), III (1840), VI (1843), XI (1848), XIII (1850), XXXII (1869), XXXVIII (1875).

3 "Report to the Council of the Statistical Society of London from a Committee of its Fellows appointed to make an investigation into the State of the Poorer Classes in St. George in the East”, ibid., XI (August, 1848).

4 Ibid., p. 194. 
policemen, and, most numerous of all, labourers (road workers and builders), represented a good cross-section of the working classes. It was discovered that wages varied much more than rents. To take two extremes: the gunsmiths, with their average weekly wage of $41 \mathrm{~s} .9 \mathrm{~d}$. (total family income of $45 \mathrm{~s} .3 \mathrm{~d}$.) were paying an average rent of just over 4s. per week. Many were paying less than 3s. a week for their dwellings, while a very small number were paying over $6 \mathrm{~s}$.; at the other end of the scale were the sailors, who, with their average weekly wage of $11 \mathrm{~s} .10 \mathrm{~d}$. (total family earnings averaged $15 \mathrm{~s} .4 \mathrm{~d}$.) were forced to pay 3s.4d. per week for rent, although many had found accommodation for less than 2s.6d. per week. Bricklayers, whose wages were over fifty per cent higher than the labourers', were paying only $6 \mathrm{~d}$. per week more in rent. ${ }^{1}$ The poorly paid labourers were thus paying a much higher proportion of their wages in rents than were the skilled artisans. Single rooms were relatively more expensive to rent than were two or three roomed flats, and few rooms could be found in the district for under $2 \mathrm{~s} .6 \mathrm{~d}$. per week. The labourers who were paying on an average $3 \mathrm{~s} .3 \mathrm{~d}$. per week for rent out of a weekly wage of $15 \mathrm{~s} .7 \mathrm{~d}$. (or 19s.11d. if the total family income is taken) had to budget carefully to live in decent accommodations and still find sufficient money for clothes, food, fuel, and other necessities. As one would expect, the amount of overcrowding bore a direct relationship to the wages of the families: the labourers, for example, were sleeping, on an average, 2.5. to a bed, and living 2.2. to a room. ${ }^{2}$ These figures delighted the committee for they constituted in their eyes only a "moderate degree of crowding". The regularly employed labourers were thus

"entirely above the wretched system of sub-letting corners of the same room, which occasions such an accumulation of wretched ness, barbarism, and disease, in the few localities to which the rudest and most unsettled of the population resort."3

Earlier in the same year a committee of the Statistical Society of London had published the result of an investigation of the houses in Church Lane, St. Giles', a street inhabited by casual labourers and members of the criminal classes. Nearly every house in St. Giles' was overcrowded, it reported, and there was hardly a family which did not let some portion of its flat or single room. In one room, for example, for which 3s. per week rent was charged, there lived three families and a

1 Ibid., pp. 200-201, 208-209.

2 Ibid., pp. 211-212. The size of the room rather than the cost of beds and bedding seems to have kept the number of beds down.

3 Ibid., p. 210. 
widow with four children, in all sixteen people. ${ }^{1}$ In another house in the same district, five families, comprising nineteen people, had to live and sleep in two rooms, and along the same street, twenty-three people were living and sleeping in one small room. ${ }^{2}$ The terrible overcrowding of St. Giles' was typical of "the miserable condition of masses of the community", stated the committee, and, it continued, in impassioned tones:

"In these wretched dwellings all ages and both sexes, fathers and daughters, mothers and sons, grown up brothers and sisters, stranger-adult males and females, and swarms of children, the sick, the dying, and the dead, are herded together with a proximity and mutual pressure which brutes would resist; where it is physically impossible to preserve the ordinary decencies of life; where all sense of propriety and self-respect must be lost, to be replaced only by a recklessness of demeanour which necessarily results from vitiated minds...."3

The Statistical Society of London combined reformist zeal with objective, quantitative analysis, and above all, it went beyond a description of sanitary evils to a fiery condemnation of overcrowding. But even though the Society's special investigating committees were perceptive enough to see that overcrowding was a separate issue from sanitation, the interest of the Journal in working class housing was intimately linked with matters of general health, and when, after 1848 , the public health movement achieved its immediate objective, the Journal maintained only a sporadic interest in housing until the 1880 s, when under the stimulus of the reform agitation, it again took up the question. The circulation of the Journal was not wide, and even in the 'forties the inquiries which the Society conducted cannot be said to have added greatly to the general public's knowledge of working class living conditions.

Similar in both scope and significance to the inquiries of the Statistical Society of London were the numerous investigations conducted by the more conscientious of the local medical officers of health throughout

1 "Report of a Committee of the Council of the Statistical Society of London, consisting of Lieutenant-Colonel W. H. Sykes, V.P.R.S., Dr. Guy and F. G. P. Neilson, Esq., to investigate the State of the Inhabitants and their Dwellings in Church Lane, St. Giles's", Ibid., XI (March, 1848), p. 3.

2 Ibid., p. 5.

3 Ibid., p. 17. The Committee bitterly attacked the system of letting and subletting down to the "sides or corners of the rooms of individuals or families", which it felt was in "almost universal operation in the houses inspected...." Ibid. 
London. Although the annual reports of these men - especially Letheby (City), Evans (Strand), Liddle (Whitechapel), and Buchanan (St. Giles') - were published and circulated beyond the vestries for which the medical officers were responsible, they had little influence upon public opinion. Only John Simon, one of the leading figures in the history of sanitary reform, ${ }^{1}$ achieved national fame and commanded the widespread attention of the public, through his annual reports, both as Medical Officer for the City of London (1848-1855), and later as Medical Officer for the Privy Council (1858-1871). Simon's reports were exceptional, for they combined sound and intimate knowledge of working class living conditions, fearless and impassioned exposés of the moral dangers of overcrowding, and repeated warnings of the political and physical dangers to the nation from slum conditions. Simon also combined a Christian Socialist brand of religious fervour with practical common-sense reform proposals, and he knew how most to appeal to his countrymen. Housing and sanitary reforms, he wrote, should interest the "public economist", "For the physical strength of a nation is no mean part of its prosperity." But generally he appealed to a higher sentiment. Slums, he wrote, were "a jarring discord in the civilisation we boast - a worse than pagan savageness in the Christianity we profess". They constituted, he stressed, "a national scandal ... something not far removed from a national sin". 3 Simon very quickly reached the conclusion that sanitary reform alone could achieve little and that overcrowding was a deep moral as well as physical problem. In his Eighth Report of the Medical Officer of the Privy Council (for the year 1865 ) he explained why his reports and interests went beyond a narrow definition of public health:

"Though my official point of view is one exclusively physical, common humanity requires that the other aspect of this evil should not be ignored. For where 'overcrowding' exists in its sanitary sense, almost always it exists even more perniciously in certain moral senses. In its higher degrees it almost necessarily involves such negation of all delicacy, such unclean confusion of bodies and bodily functions, such mutual exposure of animal and sexual nakedness, as is rather bestial than human."4

1 For Simon and a brilliant analysis of the public health movement see R. Lambert, Sir John Simon, 1816-1904 (London, 1963).

2 PP, 1857-8, XXIII, "Papers relating to the Sanitary state of the People of England, by E.H. Greenhow, introduction by John Simon", p. xlviii.

3 J. Simon, Reports Relating to the Sanitary Condition of the City of London (London, 1854), pp. $x$, xiv.

4 PP, 1866, XXXIII, p. 421, "Eighth Annual Report of the Medical Officer of 
In his official reports Simon, like other medical officers, spoke with a frankness (in his own words he lifted "a curtain which propriety might gladly leave unraised") which was denied writers aspiring to a more general readership. ${ }^{1}$ In his First Annual Report as medical officer to the City of London (a report which made Simon a national figure; all the copies printed by the Corporation were quickly sold, and the Report was serialised in the Morning Herald and reproduced in other papers) Simon wrote that in London there were swarms of families to whom

"personal cleanliness is utterly unknown; swarms, by whom delicacy and decency in their social relations are quite unconceived. Men and women, boys and girls, in scores of each, using jointly one single common privy; grown persons of both sexes sleeping in common with their married parents; a woman suffering travail in the midst of the males and females of three several families of fellow-lodgers in a single room; an adult son sharing his mother's bed during her confinement ... [swarms in] the uttermost depths of physical obscenity and degradation." 2

In his Second Report (which sold out in three weeks; it was reissued and sold by the Sanitary Association and was well publicized in the newspapers), Simon repeated his condemnation of the moral hazards of overcrowding in even more direct language. Families were styed together "in the promiscuous intimacy of cattle ... in all offices of nature they are gregarious and public; ... every instinct of personal or sexual decency is stiffled; ... every nakedness of life is uncovered there."3

Simon, and other medical officers of health, The Builder, Lancet, (the medical journal : it published several reports from its own committee of inquiry into slum conditions), and the Journal of the Statistical Society of London, constituted a pressure group which, without doubt, had a great influence upon sanitary legislation and the development

the Privy Council, with Appendix 1865", p. 207. Simon continued: "To children who are born under its curse it must often be a baptism into infamy." Dr Conway Evans, in his Second Annual Report Relating to the Sanitary Condition of the Strand District (London, 1858), drew up similarly strong charges against overcrowding. Evans worked hard to convince his vestry that sanitary improvements did not consist solely "in works of drainage and water supply", ibid., p. 80 . 1 J. Simon, Second Annual Report to the Hon. the Commissioners of Sewers of the City of London (London, 1850), p. 150. Lancet, the journal of the medical profession, circulated outside the profession, and was also most frank. Simon's reports were, of course, reported in the daily papers.

2 J. Simon, Reports Relating to..., pp. 44-45.

3 J. Simon, Second Annual Report .... pp. 148-149. Simon also drew attention to incest. See p. 200, n. 1 below. 
of public medicine, but for all their energetic and enthusiastic work they had little impact upon the public opinion in which Simon had so much faith. ${ }^{1}$ The problem of overcrowding had not yet been successfully brought to the attention of the general public and housing had yet to become a major issue. Between the great public health movement of the 1840 s and the 1880 s the press's interest in housing reform was very sporadic, and no major political figure, with the exceptions of Lord Shaftesbury and Richard Cross, Disraeli's Home Secretary, strenuously championed the cause of housing reform. ${ }^{2}$

The problem of the slums despite the wealth of information on them briefly indicated above, failed to capture the public's imagination for several reasons. Throughout the 'fifties and 'sixties the nation was more concerned with readily discernible abuses than with the less visible domestic arrangements of the working classes. Quite understandably, external evils were tackled before internal evils, the solution of which required a body of inspectors and a violation of domestic privacy. The medical profession still adhered to the miasmic theory of disease, and had yet to fully accept the importance of personal hygiene and overcrowding upon health. ${ }^{3}$ Also, crude death-rate figures, though unreliable as an indication of improvement in the slums, were accepted by the mid-Victorians upon faith, and mortality figures did show an encouraging decline in these decades. ${ }^{4}$

1 Simon confidently looked forward to "the systematic publication of facts and to the influence of general opinion as the main agencies of cure", quoted in Lambert, p. 264.

3 If we take the City Press and Lancet as examples of a newspaper and journal which took a sincere interest in working class housing, we find that the former carried a great deal of material on the subject in 1857, 1861-3, 1875, 1881-5, and almost nothing in the years, 1858-60, 1864-74, 1876-77. Lancet's pages were full of housing reports and investigations into living conditions between 1883-6, but apart from the years $1861,1866-7,1870,1874,1879$ and 1882 , it carried little information between 1859 and 1883. Lancet's claim that it had "forestalled the 'Bitter Cry of Outcast London' by denouncing the vile dens into which the extreme poor were huddled together", is in part true; but the reports of its special sanitary commission were never as graphic or as powerful as Mearns' pamphlet. See Lancet, March 8, 1884, p. 441.

3 In addition to Lambert, see Jeanne Brand, Doctors and the State. The British Medical Profession and Government Action in Public Health, 1870-1912 (Baltimore, 1965), esp. p. 38. "It was not until the last twenty years of the nineteenth century that the germ theory of disease took hold", Ibid., p. 37.

- Lancet (April 19, 1884, p. 719) pointed out that deaths in hospitals of ten helped to disguise the real mortality figures of a district. Using Clerkenwell as an example it showed that dangerous overcrowding and low death-rates could be found together in one area. The decline in death rate (23.4 deaths per 1,000 in $1851: 20.8$ per 1,000 - the lowest of the century - in 1883) was not dramatic, but was a major achievement, given the enormous increase in population. 
Although the annual and decennial census figures, publicised in the papers, revealed that London was growing at an alarming rate through a combination of internal growth and migration, ${ }^{1}$ until the 1880 s there was little appreciation of the demographic pressures upon urban housing and of the resulting increase of overcrowding and room density figures. The slums, when they were attacked, whether in London, Birmingham, or Glasgow, were generally attacked in the name of city "improvement", and the destruction of working class housing was often in the cause, not of slum-clearance per se and re-housing, but of commercial venture and civic beautification. Thus the great street improvements of this period in London and the building of the Embankment and Law Courts led to wholesale destruction of working class property and little re-housing of the evicted - a fact which was widely publicised by housing reformers, and which, with railway building in London during the same years, did at least draw public attention to working class districts. ${ }^{2}$ Even the much publicised city improvements in the heart of Birmingham, begun during Chamberlain's mayoralty (1873-6), displaced far more than they re-housed. As the broad thoroughfares which cut through the slums were completed, the slum dwellers were thrown back, and were packed more and more closely together in the already crowded courts and alley-ways out of the public gaze. The transformation of the City of London into a nonresidential commercial and banking area had the same effect. Out of the public eye, the most densely populated districts, whether inhabited by the criminal or the respectable classes, the casually employed or the artisan class, became areas through which it was no longer necessary to travel and which thus became unknown to the middle and upper classes. Travel by railway to and from the suburbs might at best give the more comfortable classes a fleeting glimpse at how the poor lived. ${ }^{3}$ As the very worst rookeries were torn down to make way for thoroughfares

1 Between 1801 and 1851 the Administrative County of London increased its population from 959,310 to $2,235,522$. By 1881 Greater London had a population of $4,766,661$.

2 See G. Godwin, Town Swamps ..., pp. 2-3; Hansard, Vol. CCXXX (1874), p. 455; Royal College of Physicians, Memorial on the Condition of the Dwellings of the Poor in London (London, 1874) p. 1; City Press, February 15, 1862; G. Buchanan, Sanitary Statistics and Proceedings of St. Giles' District (London, 1863), p. 4. See also H. J. Dyos, "Railways and Housing in Victorian London, I", in: Journal of Transport History, II, No I (May, 1955). For "improvements" see P. Edwards, London Street Improvements (London, 1898).

3 Sometimes, perhaps, more than a fleeting glance: "The payment of sixpence ... secures ... the privilege of looking from the carriage window into the apartments of all the upper-floor inhabitants between Fenchurch Street and the Station in St. George's-in-the-East; ...", Household Words, November 16, 1850, p. 172. 
like New Oxford Street, it is understandable that pride in the transformation of the face of the metropolis was stronger than the desire to ask what became of the evicted.

When men in the mid-Victorian period did engage themselves in the question of adequate housing for working men, there were many factors which prevented them from regarding it as a most urgent social and political problem. The process of slum creation was an insidious one and rarely immediately apparent or visible. The worst fever dens and criminal haunts were known, but the widespread letting and subletting, which led to overcrowding in what were once respectable neighbourhoods often went undetected. As the middle class escaped to their suburban "mon repos", their houses were taken over by the working classes. Thus the worst overcrowding often existed behind the most respectable façades, and was in many cases a hidden evil. ${ }^{1}$ Since the extent of overcrowding was difficult to detect, until the reform agitation of the early 1880 s led to investigations which proved that overcrowding was a widespread evil, the Victorians were confident that they would win the battle of the slums. Throughout the century, down to the $1880 \mathrm{~s}$, laissez-faire private enterprise had to be proved wanting before the Victorians would accept the inevitability of political action and government sponsored social reform. During the period 1850-1880 the Victorians had great faith in the power of model dwelling companies and efforts such as those of Octavia Hill to provide adequate housing for the working man. The characteristic solution of the time was what was called "five per cent. philanthropy" or "semiphilanthropic capitalism" - a happy marriage between idealistic philanthropic endeavour and straightforward business enterprise. During the thirty years after 1850 public trusts such as the Peabody Trust, and model dwelling companies, like the Improved Industrial Dwellings Company or the Metropolitan Association for Improving the Dwellings of the Industrious Classes were so active and so much in the public eye that it is understandable why to many people they represented a full solution to the housing question. In fact, the optimism was hardly justified for not only were the companies incapable of providing accommodation at rents the very poor could afford, but they were not building on a scale to keep up with population increase, let alone take care of the thousands living in the slums. ${ }^{2}$ In 1884 the twenty-eight

I For the insidious development of the slums see T.M. Torrens, "What is to be done with the Slums?", in: Macmillan's Magazine, XXXIX (April, 1879), pp. 542ff. For bad overcrowding behind respectable façades, see PP, 30 (1884-5), RCHWC I, p. 12.

2 There is no really good study of the model dwelling companies. Ashworth has some useful information. See also J. Tarn, "The Peabody Donation Fund: The 
largest corporations and individuals connected with semi-philanthropic model housing had accommodated only 32,435 people, ${ }^{1}$ and by then even men intimately connected with the dwelling companies had to admit the five per cent. philanthropic movement had not achieved its object. $^{2}$ Not until the enormity of the problem was grasped did men lose faith in the model dwelling movement. In a similar manner the period from 1860-1880 witnessed an almost universal belief in the effectiveness of Octavia Hill, that remarkable housemanager. Miss Hill eschewed anything bordering on charity (she, too, adhered to the "five per cent." philosophy) and captured the imagination of her generation and won great fame by trying to improve slum dwellers together with their dwellings. ${ }^{3}$ Her method was to proceed piecemeal, on a very small scale, patching up individual houses and constantly interfering in the lives of the lodgers with the purpose in mind of moral elevation. Octavia Hill's place in the history of housing reform is most significant, for it reveals not only the inability of reformers of the period to grasp the complexity and size of the housing problem at a time when the population of London was increasing by over twenty per cent. each decade, but also their insistence that character was, even more than environment and certainly more than economic and social factors, responsible for poverty, uncleanliness and overcrowding. Given the social philosophy of the age it was possible to dismiss the slums as products of the slum dwellers, and to argue that it was the pig that

Role of a Housing Society in the Nineteenth Century", in: Victorian Studies (September, 1966). The largest of the building companies, the Improved Dwellings Co., had by 1880 , after seventeen years of building, housed only 25 per cent. of the annual increase in London's population.

1 Ashworth, p. 84.

2 See for example, Building News, April 12, 1872. PP, 30 (1884-5), RCHWC II, p. 412. The evidence concerning the class of tenant the Peabody Trust and the model dwelling companies admitted is somewhat contradictory. See Tarn, passim, and A. Newsholme, "The Vital Statistics of Peabody Buildings and other Artisans' and Labourers' Block Dwellings", in: Journal of the Statistical Society of London, LIV (March, 1891). Various estimates of earnings of dwellers in the Peabody Estates between 1881 and 1895 range from 23s.5d. to 24s. per week. This would suggest that Peabody tenants were well-paid labourers or poorly paid artisans. At any rate not the very poorest. See PP, 30 (1884-5), RCHWC II, p. 191, PP, 7 (1881), "Select Committee on Artizans' and Labourers' Dwellings Improvement. II. Report", p. 126. Newsholme, Journal of the Statistical Society of London, LIV (March, 1891), p. 90, and A. Bowmaker, Housing of the Working Classes (London, 1898), pp. 123-4. The Improved Industrial Dwellings Co.s' tenants earned family wages of between $35 \mathrm{~s}$. and 40s. per week, which puts them in the regularly employed labourer or artisan class. PP, 7 (1881), "Select Committee on Artizans' and Labourers' Dwellings Improvement", p. 175.

8 The best biography is: W. Hill, Octavia Hill; Pioneer of the National Trust and Housing Reformer (London, 1956). 
made the sty and not the sty the pig. Adherence to Smilesian belief in self-help reinforced the conviction that it was a matter of character whether a man chose to live in a slum or not. The honest and deserving poor, the diligent, thrifty and industrious could, it was assumed, always find decent dwellings. Not until the official inquiries of the 1880 s was this comfortable belief (a product in part of years of prosperity and continuing "progress") found to be inaccurate.

Thus although there was enough published evidence to suggest that a new approach was urgently required, the period before 1880 may be characterized as one of optimistic belief in the power of private enterprise and semi-philanthropic endeavour. The prevalent approach to the slum was to pull it down: demolition rather than house provision, permissive rather than compulsory legislation, local autonomy rather than central powers, full market compensation to landlords rather than subsidized rents for tenants marks the attitude of the period and influenced the Torrens and Cross Acts, ${ }^{1}$ which in the ' 60 s and ' 70 s were passed to facilitate the demolition of slum property. The failure of these acts (which prompted the appointment of a select committee, whose reports helped to publicize the plight of the London slum dwellers) was inevitable given the philosophy behind them. ${ }^{2}$ Even though the housing question, as one contemporary pointed out in 1881 had for decades been "more or less continuously agitated", 3 there was no public clamour for positive legislation or new thinking on the subject, nor was housing yet acknowledged to be a problem serious enough to occupy the time of leading politicians. The competence of private enterprise and philanthropy to provide sufficient housing to cure overcrowding was not seriously challenged, and the concept of municipal governments being authorized to use the rates to build and maintain subsidized low cost housing had yet to be widely suggested as a solution to the "housing question". Indeed, to many, the slums were still unknown, and the "housing question" still a problem of "nuisances", unsanitary dwellings and faulty water supply.

A few months before the publication of The Bitter Cry there appeared in the Pictorial World a series of superbly written, disturbing articles by

1 The Torrens Acts $(1868,1877)$ were largely concerned with the improvement of single houses: the Cross Acts $(1875,1879)$ were concerned with larger areas. Both were hampered by their complicated workings, and the costly compensation clauses. Both were more concerned with demolition than with house building. ' See PP, 7 (1881), 'Select Committee on Artizans' and Labourers' Dwellings Improvement".

${ }^{3}$ Dwellings of the Poor (Report of the Dwellings Committee of the Charity Organisation Society) (London, 1881), p. 1. 
George Sims, which were later gathered (after The Bitter Cry proved a success) to form a short book, How the Poor Live. The articles were much more penetrating and compelling than anything that had previously appeared in the press, and they caused such a stir that the Daily News began two regular columns, "Homes of the London Poor" and "Evenings with the Poor", besides a regular correspondence page devoted exclusively to working class housing. ${ }^{1}$ In addition to being a journalist, G. R. Sims was a prolific man of letters, and his numerous writings in journalistic, novel, play, poem, and short story form (his most celebrated work was "Christmas Day in the Workhouse") earned him the titles of "the Dante of the London Slums" and the English Zola. ${ }^{2}$ His writings formed the subject of several working men's lectures and sermons. ${ }^{3}$ Sims was considered such an authority on the slums, especially the Mint and Borough districts of the City, and his descriptions were so provocative and alarming that he was called as a witness before the Royal Commission on the Housing of the Working Classes (1884-5), the only journalist to receive this mark of importance. Sims' technique was to treat the London labourer as the savage of a strange country and to conduct his adventuresome readers upon a guided tour into darkest London to visit the homes of the "one roomed helots".4 Although he was often carried away by his facile rhetoric, Sims was full of acute and intelligent observations upon the housing crisis and the "rags, dirt, filth, wretchedness, ... rotten floors, oozing walls, broken windows, crazy staircases, and tileless roofs" of the slums. ${ }^{5}$ Sims' writings had a particular value, for they were among the first to impress upon the general public that the housing shortage and high rents were combining to force the respectable poor to herd together with the criminal poor and thus bring up their children in a tainted moral environment. Rooms were too hard to come by for respectable men to forego "just because of the trifling inconveniences of overhearing a few outrages and murders", he wrote, and thus, the worst effect of overcrowding was "the moral destruction of the next generation". Sims praised the poor for not being more despairing and degenerate than they were and he called upon the government to "exercise ordinary paternal care over its family" before the poor finally lost their patience and revolted against the uncaring, myopic upper

1 The Daily Telegraph, in late 1883, also ran a regular column on housing, entitled "Why Should London Wait?"

2 G. Sims, How the Poor Live and Horrible London (London, 1898), preface.

3 Illustrated London News, November 17, 1883.

- Sims, p. 3.

Ibid., pp. 45-6.

- Ibid., pp. 12, 13. 
classes. ${ }^{1}$ In addition to calling for a more paternal spirit from the government, Sims pleaded for a more fraternal attitude on the part of the upper classes. Indeed, he felt that it was "the increased wealth of this mighty city which has driven the poor back inch by inch, until we find them today herding together, packed like herrings in a barrel, neglected and despised, and left to endure wrongs and savage hardships". ${ }^{2}$ In Darwinian tones Sims wrote that "the increased civilisation of this marvellous age" had brought victory to the strong only, and had left the "weak, the poor and the ignorant" to work out the "theory of the survival of the fittest to its bitter end". ${ }^{3}$

Sims was a brilliant agitator, for his articles contained all the right ingredients in just the right proportions - wit, broad humour, sympathy, pathos, moral indignation, dire warnings, optimism, practical suggestions. His appeals were never annoying or wearisome. His influence was certainly great; the author of The Bitter Cry acknowledged his debt to Sims and contemporaries mentioned How the Poor Live in the same breath as The Bitter Cry. ${ }^{4}$ Yet for some reason Sims' writings did not make a lasting impression upon public opinion, and they had no impact at all upon parliament. They were not taken up and quoted at length in the daily press. Sims had written to enlist "the sympathies of a class not generally given to the study of "low life"'5, but by and large his appeal was confined mostly to those already committed to housing reform. His great desire - "to awaken in the general mind an interest in one of the great social problems of the day" 6 - cannot be said to have been realized. There was no noticeable quickening of the pace of reform, no great stir in the country, no immediate parliamentary response.

Despite some exaggeration, the Pall Mall Gazette was thus correct to single out The Bitter Cry as the beginning of a new period of heightened public interest in the slums of London. Though by no means novel or original, ${ }^{7}$ the pamphlet accomplished what Sims had hoped to achieve - it stirred the nation, angered and alarmed the public, quickened the conscience of the Victorians, and made the demand for immediate reform irresistable. In the furore following its publication,

1 Sims, p. 107.

2 Ibid., p. 3.

3 Ibid. Sims was never very concrete in his demands. He called in general for stronger legislation and stronger government action, but he did not specify in which direction.

4 See for example, City Press, May 13, 1885.

5 Sims, How The Poor Live and Horrible London, preface.

B Ibid., p. 103.

7 This point is made by both Inglis, pp. 68, 69, and by J. A. R. Pimlott, Toynbee Hall. Fifty Years of Social Progress, 1884-1934 (London, 1935). 
"the bitter cry" and "outcast London" became household phrases and slogans, the very sound of which conveyed more to politicians and the general public than all previous reform literature. To try to account for its enormous success is to probe not only behind that well-worn cliché, the "Victorian Christian conscience", but into the workings of Victorian reform, and attitudes towards government and society, in one of the great transitional decades in Victorian England.

The Bitter Cry of Outcast London, a twenty page pamphlet with the sub-title "An Inquiry into the Condition of the Abject Poor", was published in mid-October, 1883. Its authorship was disputed and has remained in some question, but there can be little doubt that the Rev. Andrew Mearns, Secretary of the London Congregational Union, and at one time a Congregational minister in Chelsea, wrote the pamphlet. ${ }^{1}$ Mearns' primary purpose was to stimulate his readers to help in the task of evangelizing the inhabitants of the slums, but his pamphlet was as much a plea for an improvement in housing conditions and, coming as it did from the pen of a clergyman, was startling to a society not yet accustomed to seeing churchmen in the vanguard of housing reform. ${ }^{2}$

Much of Mearns' success stemmed from his clever choice of title. "The Bitter Cry" and "Outcast London" were ringing phrases which combined to make a persuasive and provocative title that was also a call to arms. Separated or joined, they could convey different meanings to different men, but above all they constituted a scriptural injunction to right a terrible wrong, and they also "expressed exactly that mood of corporate guilt and apprehension with stirred some members of the comfortable classes after 1880 to lend a hand to their poorer brothers."3 In one form or another the title was incorporated into several reform tracts after $1883 .{ }^{4}$

1 See Inglis, p. 67, n. 1. Pimlott attributed the work to W. Preston, as did others. Mearns told the Royal Commission that he was the author, and claimed in the pages of the Daily News and Contemporary Review (December 1,1883), p. 933, to have written The Bitter Cry. He was solely responsible for the final editing and revision of the pamphlet. For the dispute between Mearns and Preston, who wrote much of the original draft, see Daily News, April 8, 10, 12 and 15, 1884.

2 There were exceptions. Bishop Blomfield, Bishop of London had taken an interest in early sanitary reform. See also Rev. C. Girdlestone, Letters on the Unhealthy Condition of the Lower Class of Dwellings, especially in Large Towns (London, 1845). Cardinal Manning took an active interest in housing reform. I Inglis, p. 69.

- "The Bitter Cry" and "Outcast London" provided many newspapers and journals with headings for leaders; see for example The Malthusian, No 57 (December, 1883), and Reynolds Newspaper, December 2, 1883. Among the contemporary pamphlets and articles which incorporated Mearns' title were: The Rev. C. Carruthers, The Root of the Matter; or the Only Cure for the Bitter Cry of Outcast London and other Similar Evils of the Present Day (London, 1884), F. Crozier, 
Mearns began on a dramatic, if somewhat unoriginal note - the churches had so neglected their duty that every day the gulf was widening "which separates the lowest classes of the community from our churches and chapels, and from all decency and civilisation".1 That the idea of going to church had "never dawned upon these people"2 was hardly surprising, he wrote, given "THE CONDITION IN WHICH THEY LIVE". With these block capitals Mearns led his readers into the second section of The Bitter Cry, in which he powerfully argued that non-attendance at church was the result of the slum environment and home conditions. Throughout his pamphlet Mearns assumed, like Sims, that his readers were ignorant about slum conditions, and he proceeded in long, shocking, and detailed descriptions to initiate them into the horrors of the poorer working class districts of the Mint and Southwark. Even to struggle through the courts "reeking with poisonous and malodorous gases arising from the accumulations of sewerage and refuse"3 was a terrible ordeal, but it was necessary in order to reach "the dens in which thousands of beings who belong as much as you to the race for which Christ died, herd together". ${ }^{4}$ Having brought his readers safely to the threshold of the rooms, Mearns described in the blackest terms, though with little exaggeration, the homes of the poor. The average size of the rooms was eight feet square; the buildings were flimsy and in great disrepair; the windows were covered with rags or boards to keep out the wind and rain; ${ }^{5}$ and filth was everywhere in evidence. ${ }^{6}$

Methodism and 'The Bitter Cry of Outcast London' (London, 1885), The Rev. J. Long, The Hopeful Cry of Outcast London (London, 1884), G. MacCree, Sweet Herbs for the Bitter Cry or Remedies for Horrible and Outcast London (London, 1884), the Rev. F. Smiley, The Evangelization of a Great City or the Churches' Answer to the Bitter Cry of Outcast London (Philadelphia, 1890), Rev. S. Barnett, "The Remedy for Outcast London", in: Daily News, December 6, 1883, Countess Tankerville, A Bright Spot in Outcast London (London, 1884), Down in the Depths of Outcast London: Being Facts Not Recorded in the 'Bitter Cry' (1884). The title was used by one medical officer to give greater force to the heading of his annual report. See Lancet, February 2, 1884, p. 213. For "The Housing of Outcast Liverpool", see Pall Mall Gazette (November 7, 1883), and for "The Rehousing of Outcast Glasgow", Ibid. (November 28, 1883).

1 The Bitter Cry of Outcast London (London, 1883), p. 2.

2 Ibid. For a similar connection between lack of religious belief and the slum environment see Rivington, p. 17.

- The Bitter Cry, p. 4.

Ibid.

s Do-gooders like Octavia Hill were always insisting upon fresh air in the houses of the poor. They failed to realise that the frail, undernourished bodies of the poor could not withstand fresh streams of cool air, and however foetid the atmosphere the inhabitants of the slums rarely opened their windows.

Ibid., pp. 4-5. 
Had Mearns merely described the physical state of the streets, houses, and rooms of the slums he would still have greatly assisted the housing reform movement, for he described them with a force and vigour that was fresh and startling. But he proceeded from the physical state of the buildings to emphasize in unforgettable passages the terrible overcrowding within. "Every room in these rotten and reeking tenements houses a family often two", he wrote, and he proceeded to pile example upon example to stamp upon his reader an ineradicable picture of overcrowding:

"Here lives a widow and her six children, including one daughter of 29, another of 21, and a son of 27. Another apartment contains father, mother, and six children, two of whom are ill with scarlet fever. In another, nine brothers and sisters, from 29 years of age downwards, live, eat and sleep together. Here is a mother who turns her children into the street in the early evening because she lets her room for immoral purposes until long after midnight, when the poor little wretches creep back again if they have not found some miserable shelter elsewhere."1

Mearns also described the sweating industries, such as match-making and rabbit-fur pulling, which were carried on in the rooms, making the cramped, unventilated quarters even more abominable. ${ }^{2}$

Mearns' Bitter Cry, with its emphasis upon overcrowding and its deemphasizing of matters of sanitation and sewerage, thus performed the valuable task of informing the general public of what medical officers and other housing reformers had known for years and had been vainly trying to publicize - that overcrowding was a moral and physical evil in itself, quite divorced from larger sanitary questions. ${ }^{3}$ Although Mearns, like Sims, titillated his readers by hinting at "horrors and abominations" which "no respectable printer would print and certainly no decent family would admit ....", and although he claimed that he had for propriety's sake toned down all his descriptions, he in fact pulled few punches, and was startlingly explicit. ${ }^{4}$ His discussion of the sexual immorality produced by overcrowding was very much franker than anything that had appeared previously, and added enormously

1 Ibid., p. 5.

2 Ibid., pp. 9ff. Eventually in 1888 a select committee of the House of Lords was appointed to investigate the sweating trades.

3 In addition to the medical officers, and members of the Statistical Society of London, mentioned above, Lord Shaftesbury and Dr Southwood Smith also clearly saw, and wrote about, the connection between overcrowding and immorality.

4 Ibid., pp. 2-3. Sims had hinted at "nameless abominations which could only be set forth were we contributing to the Lancet,...", Sims, p. 45. 
to the fame or notoriety of The Bitter Cry. Mearns was merely following earlier writers when he described the drunkenness, prostitution, crime, and mingling of sexes in the slums, and both Greenwood and Sims had related before Mearns how exceptional and unfashionable marriage was in the rookeries. ${ }^{1}$ But Mearns was the first to state in unequivocable terms, that, as a result of overcrowding, "incest is common; and no form of vice or sexuality causes surprise or attracts attention". ${ }^{2}$ A vice condemned in savages was, it seemed, practised in the very centre of the empire which was being acquired in the name of Christianity and civilisation. Nothing brought a greater sense of urgency to the housing reform movement than this daring declaration, based upon the researches of church missionaries, that incest was common. It occupied, as we shall see, the attention of the Royal Commission on the Housing of the Working Classes, and provided the shock required to turn polite interest in the slums into serious, committed concern.

Mearns did not offer many practical solutions to the misery he had described. He condemned existing housing legislation for making matters worse by demolishing without re-housing the evicted at rents they could afford, and he ended by calling rather vaguely for both state action and private philanthropic endeavour - a combination typical for the time. He wrote that nothing could be achieved on a large scale without state interference, and he concluded that the environment had first to be improved before the missionary could accomplish anything. ${ }^{3}$

Mearns' frank admission that evangelizing efforts were futile in such bestial surroundings, his statement that the missionary needed the state's assistance, and his plea for government intervention and better

1 Both Sims and Mearns regarded drink as almost a necessity to endure life in the slums. For marriage as the exception rather than the norm among people living together see Greenwood, The Seven Curses of London, pp. 15-16, and Mearns (quoting Sims), Bitter Cry, p. 7.

2 Ibid. This reference to incest is the only one I have been able to find in housing reform literature up to that time. But here, as in other aspects of housing reform, the remark of the Medical Press Circular, in November, 1875 - "We cannnot fail to draw the conclusion that medicine ... is, at present, and is likely to remain for some time to come, far in advance of public opinion and support" - has special application. Sir John Simon, according to his latest biographer, often played upon "Victorian prudery in an effort to shock his readers into sympathy". (Lambert, p. 15). In his Second Annual Report as Medical Officer to the City, Simon stated that overcrowding made the habits of the slum dwellers "ruffianly and incestuous" (Simon, Reports Relating to .... p. 150). Lancet (February 22,1868, p. 265) reported a meeting of the Health Officers' Association in which it was declared that overcrowding had increased to a point where "sex and consanguinity count for nothing". See also Ibid., August 4, 1883, p. 187.

3 The Bitter Cry, p. 14, p. 20. Mearns offered more definite suggestions in a paper he read at a meeting on June 4, 1884. He wanted legislation governing, and inspection of, all property let in single rooms. Pall Mall Gazette, June 5, 1884. 
housing, marks The Bitter Cry in strong contrast to earlier works dealing with London's heathens. When compared to earlier evangelical tracts, the scope, daring, and this worldly attitude of The Bitter Cry is apparent. ${ }^{1}$ In its fierce indignation, reform fervour, powerful logic, integrity, and carefully chosen descriptions, Mearns' work could be rivalled only by the annual reports of the local medical officers of health. It was certainly unique as a popular reform pamphlet designed for a wide market. Mearns married the sharp eye of the journalist or medical inspector for the most damaging details with the moral fervour of the evangelical missionary. Combining revelations concerning moral, physical, and spiritual degradation in the centre of London, his pamphlet could not fail to elicit the strongest response from social reformers, philanthropists, responsible politicians, and men of sensibilities.

The Bitter Cry was a direct challenge to complacency about declining deathrates and sanitary improvements. No longer was it possible to find comfort in the broad thoroughfares which existed where once there were slums. Mearns' pamphlet forced attention upon conditions within working class houses and compelled one to look beyond vital statistics to the moral and physical effects of overcrowding. Although Mearns had concentrated upon the "outcast" and "abject poor" he had failed to define those terms and he had also refused to draw the line between the criminal and respectable poor who were thrown together by the scarcity and dearness of accommodation. ${ }^{2}$ His work could be - and in fact was ${ }^{3}$ - dismissed by some as gross exaggeration, but it could hardly be ignored. Lancet whose long interest in housing reform was greatly heightened by The Bitter Cry, noted at the end of 1883 that all previous reformers had "preached almost to deaf ears" and had "till very lately scarcely ruffled the conscience of political men". 4 With The Bitter Cry a new stage in the housing reform movement was marked, a stage characterized by its divorce from sanitary problems, and by a new emphasis upon overcrowding and the forces of supply and demand.

The great success of Mearns' pamphlet ${ }^{5}$ must be attributed in part

1 See for example R.W. Vanderkiste's Notes and Narratives of a Six Years' Mission, principally among the Dens of London (London, 1854). See also the tract written the year after Mearns' by F. Crozier. Both Vanderkiste and Crozier's experiences in the slums led them to call for more bibles rather than more houses.

2 In this Mearns was following Greenwood, Sims and Simon.

3 See p. 225, n. 2 below.

4 Lancet, December 15, 1883, p. 1050.

5 This must be measured in its impact rather than in the numbers sold, although a contemporary did claim that it "sold by millions" (F. Rogers, Labour, Life and Literature - Some Memories of Sixty Years (London, 1913), p. 102. It passed through several editions. 
to the publicity which it received in the Pall Mall Gazette. The editor, W. T. Stead, with his brilliant sense of timing, immediately took hold of The Bitter Cry, and stripping it of much of its religious content by playing down its evangelical appeal, ${ }^{1}$ used it as his principal example and argument in a powerful campaign against the city clums. Stead claimed that he "called the attention of the world" to The Bitter Cry; in so doing he achieved not only "the first great coup" for the newspaper under his editorship, but he guaranteed the success of the housing reform movement in the near future. ${ }^{2}$ Stead was one of the great controlling forces in English public life, and his newspaper, though its circulation was not large compared to some dailies, was one which "'everybody' had to read - which nobody could afford to miss". ${ }^{3}$ The subject matter of The Bitter Cry fitted in well with his plan to use sex and sensationalism in a new brand of journalism, and with his sincere desire to assist in "the amelioration of the condition of the disinherited".4 Stead took up The Bitter Cry before anyone else, while it was still hot off the press. On October 16, the Pall Mall Gazette carried not only an extensive synopsis of the pamphlet, but also a fiery leader entitled "Is it not time?", in which Stead called for solutions rather than empty emotion, and for a more fraternal spirit towards the poor, especially from the churches whom he bitterly castigated for concentrating upon saving men from the hell in the after-life while ignoring the hell of their lives on earth. ${ }^{5}$

The long extracts from The Bitter Cry and the impassioned leader resulted in the newspaper's offices receiving a flood of letters. On October 18 Stead published as many of these as he could, and a few days later he filled one and a half pages with correspondence under the heavy-type heading "The Bitter Cry of Outcast London". By October 22, the paper reported that it was being "inundated with correspondence from all parts of the country on the subject of the houses of the London Poor. It is impossible to find room for all the letters that reach us by every post." A A week after the first leader on The Bitter Cry, Stead published another leading article entitled "Outcast London", in which he gratefully acknowledged that letters continued to pour in about Mearns' pamphlet. The fervour of what was fast amounting to a strong social protest was intense: Stead called for "State interference" and

1 Inglis, p. 61.

2 For Stead, see F. Whyte, The Life of W.T. Stead (London, 1925).

3 Lynd, p. 368.

4 Ibid.

5 Pall Mall Gazette, October 16, 1883. Stead described working class housing as "the one great domestic problem which the religion, the humanity, and the statesmanship of England are imperatively summoned to solve".

6 Ibid., October 22, 1883. 
advised his readers to continue their agitation for more far-reaching housing legislation now that The Bitter Cry had aroused the nation to a fever pitch. "It may be long before practical reformers have another opportunity as good as the present ...", he wrote, and "If they strike now, while the iron is hot, the bitter cry will not die away ... and leave no practical good behind it as the outcome of all our sympathy and all our remorse". 1

One of the more active, though lesser known reformers of this period, the Rev. Henry Solly, once observed that "no agitation for social and political improvement can be conducted efficiently" without some organ in the press. ${ }^{2}$ Mearns was fortunate in being taken up by Stead, for the Pall Mall Gazette converted a powerful plea into a great social crusade. Other newspapers rushed to keep pace with Stead, and The Times was forced to observe, disapprovingly, that "everybody who can write or speak a few consecutive sentences" was rushing into print "with more or less fervency of rhetoric" to offer panaceas for the slum problem. ${ }^{3}$ No longer could it be said that newspapers failed to command the public's attention on housing problems sufficiently long to effect reform. ${ }^{4}$

Stead's timing was perfect for he sensed the existence of an interest which, if properly aroused, could form an irresistable reform movement. Mearns' timing had no doubt been unintentional, but the success of his pamphlet can only be understood by placing it in the context of the social psychology of the 1880 s. For despite its great intrinsic merits, it is doubtful if The Bitter Cry would have had the same impact upon an earlier generation. Why it served as the cataclyst for a successful reform agitation, the remaining pages of this paper attempt to show.

\section{III}

The Bitter Cry drew widespread attention to intolerable living conditions in the heart of London at a time of great stress and anxiety, when the social conscience of the nation was undergoing radical change. The "great depression" was a decade old, and wages, prices, unemployment, labour conditions, rents, and minimum living standards were all being subjected to critical examination. ${ }^{5}$ Faith in progress

1 Ibid. The paper later carried a series of front page articles entitled "The Dwellings of the Poor". Octavia Hill, Shaftesbury, and C.S. Loch (of the Charity Organisation Society) were among the contributors.

2 Solly Collection of Manuscripts, London School of Economics, Vol. IV, Section 4(a), item 3 .

8 The Times, November 26, 1883.

4 See the sad comment of J. Greenwood, The Wilds of London, preface.

b See Lynd, passim and H. Ausubel, In Hard Times (New York, 1960). 
under free enterprise market conditions was weakening and new views of society were being put forward. Just before the publication of The Bitter Cry, Hyndman's Democratic Federation had been formed, and just after, the Fabian Society. The extension of the suffrage in 1884 not only concluded the Victorian response to the major political challenge of the age, (thus freeing energies for social questions), but also gave a new significance to the political and social policies offered to the working man. In this age of changing values, private property no longer appeared safe from attack. In 1881 Henry George's Progress and Poverty was published in England, and by 1885 it had sold 60,000 copies, and those who could not follow his single-tax argument could still not fail to be impressed by the passion with which he pleaded his cause and the powerful description he gave of the "unequal distribution of wealth". In the view of contemporaries it did much to hasten the coming of socialism. The 1881 Irish Land Act, though designed to meet peculiar Irish needs, increased fears in England that all freedom of property contracts were about to be challenged. Indeed, soon after The Bitter Cry appeared, cries of "fair rents" for the London poor were raised, and a "no rent" movement to protest rack rents and evictions in the East End was begun. ${ }^{2}$ The Agricultural Holdings Act of 1883, which legalized compensation for tenants' improvements, represented another blow to free market conditions. The Times bitterly commented in September, 1883, that "the appearance of Mr. George's attack upon private property in land and the circulation of his work in a cheap form have probably given an impetus to speculations favourable to a particular form of socialism", and it drew attention to the fact that plans were afoot to give both the Irish peasant and the agricultural labourer "possession of the soil at the expense of the State". "The laissez-faire maxim", it concluded, "is at a discount just now." Joseph Chamberlain, who had included the improvement of the housing of the working classes as part of the Radical Programme added to the heat of the political debate by taking advantage of The Bitter Cry agitation to propound taxation of large estates as the solution to the problem of the slums. ${ }^{4}$ The Bitter Cry, therefore, exposed the horrors of urban

1 For George's impact upon England see Lynd, pp. 141ff. One contemporary observed that George, though not a socialist himself, had done more "than any other single person to stir and deepen in this country an agitation which, if not socialist, at least promises to be the mother of socialism", quoted in Ibid., p. 143. See also the Pall Mall Gazette, November 20, 1883.

2 Pall Mall Gazette, October 12, 1883; Ibid., November 1, 1883.

3 The Times, September 5, 1883.

4 See "The Radical Programme III - 'The Housing of the Poor in Towns", in: Fortnightly Review, XLIX (October, 1883); J. Chamberlain, 'Labourers' and Artizans' Dwellings", ibid. (December, 1883). 
slums at the moment when the rights of "property" were being questioned and the rights of tenants and duties of "property" were being stressed.

In this atmosphere of political tension and social uncertainties, the gulf dividing classes attracted as much notice as it had back in the hungry 'forties. The Daily News, in an article on overcrowding, a few days after the Pall Mall Gazette's coverage of The Bitter Cry, commented that "Until lately everybody was more or less content to accept the contrast between wealth and poverty as an inexorable social law. The rich accepted it sometimes complacently; the poor took it in dogged or stupid despair. But we can see for ourselves at present that every day there grows up more and more widespread the utter disbelief in the absolute necessity of the existing conditions." Many men of the time (especially those like T. H. Green who combined liberal with evangelical backgrounds), grasping the enormity of the contrast between rich and poor, found the strongest impulse towards reform in guilt and a sense of desperate shame. Beatrice Webb has brilliantly described this period as one which witnessed a "new consciousness of sin among men of intellect and men of property,..." She explained that she did not mean a sense of personal sin: "The consciousness of sin was a collective or class consciousness; a growing uneasiness, amounting to conviction, that the industrial organisation, which had yielded rent, interest, and profits on a stupendous scale, had failed to provide a decent livelihood and tolerable conditions for a majority of the inhabitants of Great Britain."2 The phrase "outcast London" heightened, and appealed to, this sense of sin, and to many The Bitter Cry was a call to the rich to turn in fraternal love to their poorer brethren.

The Bitter Cry was followed by numerous articles urging housing reform as one way of closing the gap between classes. Hugh MacCallam, in his The Distribution of the Poor in London (1883) and the Rev. Brooke Lambert in his "The Outcast Poor. I. Esau's Cry"3 called for a new spirit of brotherhood. The old spirit of noblesse oblige was combined with the new desire to reach the poor on a more intimate level, in the work of Lord William Compton, whose father possessed large working class tenements in Clerkenwell. In 1884, Compton, who was influenced by Mearns' pamphlet to take an interest in his father's property, wrote an article on "The position and duties of ground

1 The Daily News, October 19, 1883.

2 Beatrice Webb, My Apprenticeship (London, 1926), pp. 179-80.

3 Hugh MacCallum, The Distribution of the Poor in London (London, 1883); Brooke Lambert, "The Outcast Poor. 1. - Esau's Cry", in: Contemporary Review, XLIX (December, 1883). Part Two - "Outcast London" - was written by Mearns. 
landlords in London", in which he urged large landlords to take a personal and active interest in their properties and abolish the slumproducing system of house agents and middle-men. "We are told that the upper classes are neither toilers or spinners", he wrote, "but they certainly can become so." 1 Although his attitude was much more closely linked with traditional paternalism, Alfred Austin, the poet laureate, made a similar plea in the pages of the Tory organ, the National Review, of which he was editor. In an article entitled "Rich Men's Dwellings" (it had the significant sub-title, "A proposed remedy for social discontent") Austin took advantage of the recent agitation over the slums to express alarm at the flagrant ostentation of the wealthy and to call, in the tradition of Tory democracy, for a bond between classes. Austin was traditional enough to demand the usual sacrifices from the poor - abstinence, thrift, industry, and selfdiscipline; the rich, for their part, were to give up ostentatious luxuries and invest their money in working class dwellings at low, but remunerative rents. Sympathy and help were to be given freely to the poor. If the upper and lower classes would undergo moral reformation, and follow Austin's advice, wrote one correspondent to the National Review, "the social question would probably be solved". ${ }^{2}$

When a group of clergymen, meeting in Stepney in November 1883 to discuss The Bitter Cry, called for the "extension of sympathy between rich and poor", or when, in an article published in the same month proposing "the remedy for outcast London", it was suggested that the cultivated and leisured classes had to "break down the walls of separation between them and 'outcast London'", a fresh awareness of the class gulf and the relationship of urban housing conditions to it, was being expressed. ${ }^{3}$ Mearns' pamphlet in fact appeared at a time when many of the comfortable classes were making attempts to cross this class barrier and witness for themselves the awful conditions in which the masses were forced to live. Visits to the streets inhabited by the poor became increasingly common and several contemporary writers observed how fashionable slumming had become. ${ }^{4}$ Much of this slum-

1 Pall Mall Gazette, March 12, 1884. Compton later assisted housing reform by his distinguished service on the London County Council.

2 Alfred Austin, "Rich Men's Dwellings", in: National Review, No X (December, 1883), and Ibid., No XI (January, 1884), pp. 755-6.

3 Daily News, November 30, 1883; Ibid., December 6, 1883.

4 One clergyman called slumming a "West End fad" (Pall Mall Gazette, April 3, 1884). On December 7, 1883, the Pall Mall Gazette wrote "Since we directed public attention to the 'Bitter Cry of Outcast London' it has become fashionable to make a pilgrimage to the slums", and it added, "A show slum is quite in demand in many circles, but the worst slums are avoided by all but official pilgrims". For similar statements see J. Adderley, In Slums and Society (Lon- 


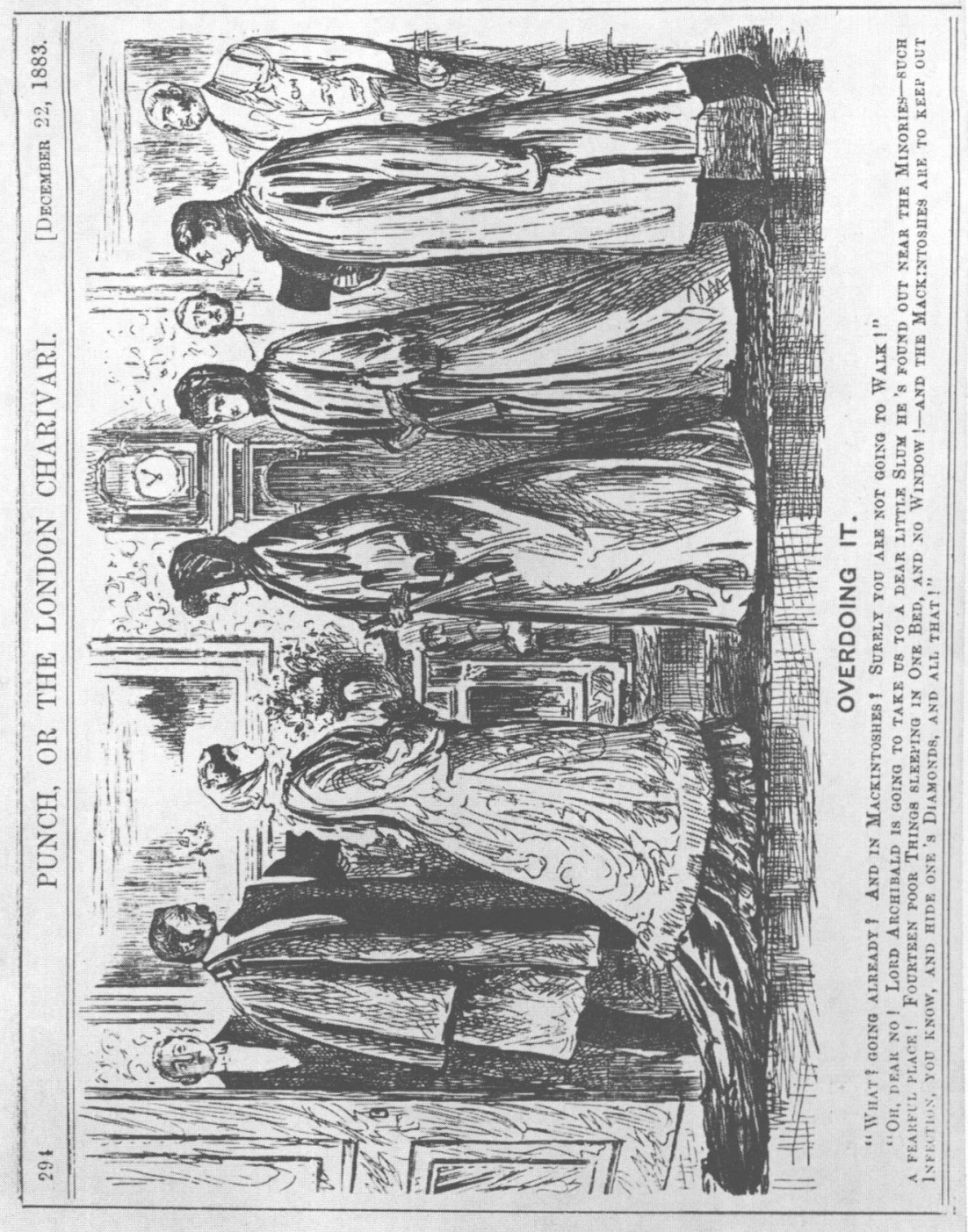


ming was, as Punch was quick to spot, merely a form of adventure and entertainment; ${ }^{1}$ but to others it must have provided a deep shock. To one man it was "like going into a strange country, where you never expect to meet any one you know, and where you are received with toleration or cold indifference". 2

Mearns' pamphlet thus had the advantage of discussing a form of social distress which was perhaps the most tangible and obvious manifestation of the class gulf men were becoming so concerned about. One attempt to bridge this gap was the settlement movement, which enabled young men of wealth and education to live among the poor and to teach them, by example, the virtues of the gentlemanly life. The Bitter Cry served as an inspiration and one of the immediate causes for the founding of the most famous of the settlements, Toynbee Hall. It is true that the settlement movement had its roots in the work of Denison, Brooke Lambert, and Samuel Barnett well before Mearns' pamphlet appeared, but not until the agitation over the London slums were the various elements necessary for the settlement movement synthesized. ${ }^{3}$ Mearns' portrayal of spiritual and physical poverty helped to crystallize the vague, long felt desire on the part of many young members of the comfortable classes to do something for the poor, and it served as a call to arms for many young Oxford and Cambridge undergraduates who previously had no thought of pursuing missionary work in the slums. Just a few weeks after its publication, the Headmaster of Harrow, the Rev. Montagu Butler, held a copy of The Bitter Cry in his hand during a sermon he preached at St. Mary's, Oxford. Butler referred to the pamphlet and with deep emotion pleaded:

"God grant that it may not startle only, but that it may be read and pondered by thoughtful brains, as well as by feeling hearts. God grant that our ablest men and women, without distinction or party, may at last persuade the nation to grapple earnestly with this supreme question of moral and physical destitution.... God grant also that here, in this great home of eager thought and enlightened action and generous friendship, 'the bitter cry of outcast London' may never seem intrusive or uninteresting, but that year by year her choicest sons may be arrested by it"."

don, 1916), p. 170, and G. Sims, My Life. Sixty Years' Recollections of Bohemian London (London, 1917), p. 136.

1 See the Punch cartoon, December 22, 1883, p. 294.

2 MacCallum, p. 7.

3 Pimlott, p. 24. See Inglis, p. 37.

- Quoted in Pimlott, pp. 29-30. 
Butler's prayers were soon answered, for Barnett was inspired by The Bitter Cry to even greater proselytizing efforts at Oxford on behalf of the godless poor of the East End. In November, 1883, he addressed a group of Toynbee's disciples in St. John's, Oxford, and, referring to the recent pamphlets and agitation, outlined the settlement idea. A few weeks later he spoke at the union on the motion that "in the opinion of this House the condition of the dwellings of the poor in our large towns is a national disgrace and demands immedatie action on the part of voluntary associations, municipal authorities, and the Legislature." The motion was unopposed. ${ }^{1}$

The settlement movement would certainly have got under way without the help of The Bitter Cry. Nevertheless Mearns' pamphlet prepared an extremely receptive soil in which Barnett could plant his ideas, for it so stirred young men that they needed little urging from Barnett to go into the slums. Although Barnett said that the undergraduates "long before the late outcry" had felt called upon to do something for the poorer classes, he drew special attention to the "strange stirring in the calm life of the universities" occasioned by the reform pamphlets. ${ }^{2}$ James Adderley, the socialist clergyman who became Head of the Oxford House Mission (an East End settlement established soon after Toynbee Hall: it placed working class housing high on its list of reforms), gratefully acknowledged Mearns' pamphlet as a turning point in his career. He described in his autobiography, In Slums and Society, how Mearns' pamphlet directed the "attention of the West End to the East". Adderley recounted how "the universities were aroused and, whereas up to the year 1883 you could count on your fingers the names of men, like Edward Denison, who had studied the social question on the spot and lived among the people", after that date it became "the commonest thing in the world" for ladies and gentlemen to go down into the East End. Adderley placed such store by The Bitter Cry that he commented that its author "ought to be canonized"."

We have mentioned above how to some men the housing of the poorer classes was part of a social organization that filled them with a deep sense of sin. A leading social reformer of this period once remarked that "the sense of sin has been the starting point of progress". ${ }^{4}$ His remark,

1 Ibid., p. 33. Before The Bitter Cry Barnett and others had raised the problem of the large towns up at Oxford.

2 Quoted in Ibid., p. 30. The Spectator considered that the settlement movement had its origins in the period when the appearance of The Bitter Cry gave rise to a "spasm of public emotion". Quoted in Ibid., p. 40. See also Inglis, p. 149.

3 Adderley, pp. 16-17.

4 Rev. Samuel Barnett, quoted in Pimlott, p. 1. Though this sense of sin was not entirely confined to religious sentiment, Ausubel is correct to state that "The 
true for much social reform is especially applicable to housing reform. Even if we exclude the broader, secular connotations of the shame, guilt, and sin many responsible men felt, and concentrate upon the narrower, religious concept, it is immediately apparent that The Bitter Cry greatly aroused a nation which was concerned with social and sexual morality. Once again the timing of Mearns' work was fortunate, for it appeared at a time when the church was just preparing to make stronger efforts to win the urban masses back to the moral and spiritual teachings of Christianity. ${ }^{1}$ It thus inspired churchmen to take up with much greater vigour the problem of the cities.

The Bitter Cry was concerned with the flesh and blood of homes rather than the mere bricks and mortar of houses. It is one of the great truisms of Victorian history that the Victorians worshipped the concept of "home". Indeed, throughout the nineteenth century housing reformers had stressed that without a Christian hearth to gather around, family life disintegrated, knowledge of the Scriptures died, obedience and purity were untaught, and all values collapsed. ${ }^{2}$ Mearns' portrayal of the extent of "heathenism" and depravity in the slums revealed that comfortable, middle-class notions of home-life were unknown there, and that in the one-roomed dwellings of the poor domestic virtue was impossible. The connection between overcrowding, and immorality and atheism had frequently been made, but not until Mearns' exposé of the extent of sin in the homes of the London poor, were the official church bodies sufficiently shocked to take an active, direct, and intimate interest in the slums. The London Quarterly Review was correct in predicting that the facts contained in Mearns' pamphlet "may well produce deep emotion", for all denominations suddenly vied with one another in their deep concern for the outcast poor of London. $^{3}$

The Pall Mall Gazette observed as early as November, 1883, that "the interest evinced in 'Outcast London' by the clergy on all hands is

biggest single influence that made people reformers in the late Victorian period was still religion". Ausubel, p. 67.

1 See Inglis' perceptive and penetrating study.

2 Lord Shaftesbury considered that "there can be no security at home, no honour, no prosperity, no dignity at home, no nobleness of attitude towards foreign nations, unless the strength of the people rests upon the purity and firmness of the domestic system", and he asked "If you have one, two or three families in the room, what can there be of the purity of domestic life?" Quoted in G. Potter, "The First Point of the New Chapter: Improved Dwellings for the People", in: Contemporary Review, XVIII (November, 1871), pp. 555-6. See also the City Press, September 12, 1857 for fear that the working man's dwelling was devoid of the "comfort, rest, peace, love, holiness" that "home" represented. 3 London Quarterly Review, January 1884, p. 322. 
a healthy sign". ${ }^{1}$ The Bitter Cry drew together the various nonconformist groups in a joint conference to discuss the spiritual and physical condition of the London masses. Several separate conferences were called to discuss the problems raised by Mearns, ${ }^{2}$ and The Bitter Cry prompted one Wesleyan Conference to observe that London was "the prize, the citadel, for which the powers of light and darkness must contend". In contrite mood the Conference concluded that it could not find sufficiently strong language "to express our sense of responsibility of English Christians in respect of the great city, its sins, and sorrows". ${ }^{3}$ In 1884 a paper on The Bitter Cry was read at a Methodist conference in London and in the same year the Wesleyan Conference noted how the "temporal and spiritual interests of the dense populations of our large towns, more especially of London, have excited much public attention through the year." 4 As a result of the agitation provoked by The Bitter Cry, the Methodist Church began to pay great attention to the problems of the cities and "It was in response to The Bitter Cry of Outcast London ... that two years later the East End Mission was born." 5 Immediately following the publication of Mearns', work, a Baptist Conference was held to determine "the churches' response to the Cry of Outcast London", in the course of which it was declared that the correct response must be "full in its tone and various in its ends. The Church must be a great deal broader in its methods, and become broader in its sympathies and work. It ought to be part of its business to study political theology." At another Baptist Conference on the "needs of 'Outcast London'" Mearns' findings were agreed to be correct, and it was emphasized that "hundreds of thousands" were living in such overcrowded rooms that "common decency is absolutely impossible, the sanctities of family life are utterly unknown, and the grossest immorality is so much a matter of course as to attract no attention". It was stressed that spiritual work in such surroundings was impossible, and the Conference concluded by petitioning the Queen for stronger municipal powers for London and called for a Royal Commission to conduct a thorough survey of housing needs. ${ }^{7}$ A few weeks after The Bitter Cry appeared a Church of England Temperance Society meeting, presided over by the Bishop of Bedford, under whose authority the

1 Pall Mall Gazette, November 7, 1883.

2 Inglis, p. 68.

Quoted in Ibid., p. 68.

4 Ibid.

- R. F. Wearmouth, Methodism and the Struggle of the Working Classes, 1850-1900 (Leicester, 1954), p. 150. See also pp. 155, 156.

- Pall Mall Gazette, November 6, 1883.

7 Daily News, November 29, 1883. 
East End lay (he later served on the Royal Commission on the Housing of the Working Classes) discussed the housing question, and at other church meetings throughout London, working class housing was discussed in an atmosphere of tense excitement, and Mearns' work was either the major topic of discussion or was quoted. It was also used as a text for sermons, ${ }^{1}$ and stimulated many individual clergymen, particularly those from slum parishes, to write or speak on the housing of the working classes. ${ }^{2}$

As part of the generally quickened conscience of the churches, the Church of England finally began to improve some of its London properties and placed several houses in the care of Octavia Hill. ${ }^{3}$ The Association for Improving the Houses of the Very Poor was established during the agitation following Mearns' pamphlet and clergymen constituted a majority on its committee. On the Lord Mayor's Mansion House Council on the Dwellings of the Poor, established in 1883, there sat the Archbishop of Canterbury, the Bishops of London and Stepney, the Archbishop of Westminster, and the Chief Rabbi - a collection of high ecclesiastics which clearly reveals the deep interest the church was now taking in the housing of the working classes.

The significance of the churches' response to The Bitter Cry lies in the fact that the physical needs of the poor created as much alarm and concern as their spiritual needs. The Bitter Cry appeared at a time when most of the churches were tentatively acknowledging the need to show more interest in this life on earth in order to win the working man back to the churches. Genuine concern about the working man's physical and moral degradation mixed with the desire to save him for Christianity in general and for one's own church in particular. Mearns' pamphlet spurred the churches, which were fully aware that moral and spriritual precepts were meaningless in the slum environment, in this movement away from abstract theology towards T. H. Green's ideal of a "society breathing the Christian spirit". As the churches became more experienced in slum missionary work, the more readily did they accept Mearns' argument that the salvation of souls required an improvement in the environment. The Founder and General of the Salvation Army, William Booth, for example, had reacted immediately to The Bitter Cry by condemning physical solutions to what he considered was a crisis of spiritual and moral character. "Nothing can be more ridiculous", he

1 Ibid., November 22, 1883, November 27, 1883, November 30, 1883, December 5, 1883, December 10, 1883, December 11, 1883.

2 For the Rev. Hugh Price Hughes' fiery reaction to The Bitter Cry see Daily News, April 4, 1884. See also: Rev. J. Edmund Long, Forster Crozier, Rev. C. Carruthers, pp. 205f., n. 4 above.

PP, 30 (1884-5), RCHWC II, p. 298. 
wrote, "than to attempt to deal with the great social difficulty, as though it had no deeper cause than a want of bricks and mortar", and as though it were a case of "mere physical appliances". ${ }^{1}$ Yet not long afterwards Booth underwent a conversion to remedies of a social and political nature, partly because further experience in the slumlands of London convinced him that the terrible conditions so debased a man that salvation was impossible, partly because the Army was not having much success in the slums. ${ }^{2}$ In his In Darkest England, Booth drew attention to "the foul and poisonous air of the dens in which thousands live" and stated squarely that society "must change the circumstances of the individual when they are the cause of his wretched condition and lie beyond his control". ${ }^{3}$ Booth's conversion to social reform owes little to The Bitter Cry, but it is worth noting that his influential In Darkest England, which marks this conversion, was largely written by his friend W. T. Stead, and that "the end of the first chapter was taken almost verbatim from the leading article in the Pall Mall Gazette on October 16, 1883, in which Stead hailed The Bitter Cry of Outcast London." 4 The housing agitation forced many churches for the first time to pay serious attention to the slums, and their experiences there, as with Booth, convinced them that they had to change the material environment. This new emphasis upon social justice was reflected in the statement of the Congregational Union in 1885 that it was the "duty of every Christian" to work for the "better housing of the poor and the relief of overcrowding in the cities". The following year a writer in the Methodist Times summed up this new spirit by insisting that "the duty of the Evangelical is not simply to preach the Grospel, but if the condition of his hearer is unfavourable for his reception, it becomes his duty also to improve those conditions ...."5 In 1845, the Rev. Charles Girdlestone, is his work on the condition of the working classes, had had to apologise for taking an interest in the outer condition of men rather than dealing exclusively with their souls. ${ }^{6}$ Forty years later, at the height of the housing agitation, a clergyman would practically have had to apologise for not taking an interest in the condition of the working classes. Public opinion increasingly expected clergymen to be "more than mere preachers", for, in the words of a correspondent to the Pall Mall Gazette shortly after that paper's summary of The Bitter Cry, "They must not allow their anxiety about a

1 Pall Mall Gazette, November 22, 1883.

2 Inglis, p. 197.

3 Quoted in Ibid., p. 195.

4 Ibid., p. 203.

5 Quoted in Ibid., pp. 296, 259.

6 The Rev. Charles Girdlestone, passim. 
future life, which most of those to whom they would preach have ceased to believe in, to obscure their vision with regard to the truly awful condition" in which the poor are forced to spend their days. ${ }^{1}$

The Bitter Cry helped the churches to admit openly that they were faced with a desperate urban challenge, and it pointed the way to a possible solution. It must therefore take the credit for accelerating the movement of the church into the slums. In so doing it greatly assisted the housing reform movement, and played a significant role in the transformation of the churches' social philosophy in the late nineteenth century. The widespread interest of religious bodies in working class living conditions gave the housing reform movement a new ally, and at the same time enabled the church to adopt a modern, progressive social philosophy. The rebuke of one housing reformer - "How often the stately church seems to mock the squalid slum-dwelling near at hand, and the squalid slum-dwelling to rebuke the stately church" - had less validity after $1883 .^{2}$

Mearns' revelations of sexual promiscuity and immorality were of vital concern to all respectable Victorians, but especially to the Church, which was the guardian of the nation's moral standards. The Royal Commission on the Housing of the Working Classes devoted much energy to an examination of the connection between overcrowding and immorality, and especially to Mearns' statement about incest. The two churchmen on the Commission, the Bishop of Bedford, who had an intimate knowledge of the East End, and Cardinal Manning, who was an active social reformer, could derive little comfort from the witnesses, many of whom agreed with Mearns that overcrowding did produce incest. Mearns was himself examined, and was in fact forced into an ambiguous defence of his statement that "incest is common". ${ }^{3}$ However, Lord Shaftesbury, who was not given to sensationalism or to feeding the idle curiosity of the day, told the Royal Commission, that the oneroomed system led to the one-bed system, and that the effects of this were shocking. The veteran reformer gave examples of ten and eleven year old children "endeavouring to have sexual connection" in imitation of their parents. ${ }^{4}$ Mearns' revelations of sexual vices were, as the

1 Pall Mall Gazette, October 17, 1883.

2 G. Haw, Christianity and the Working Classes (London, 1906), pp. 17-18. See also Inglis, p. 151. Novels dealing with the lives of clergymen in the slums, such as Mrs Humphrey Ward's Robert Elsmere (London, 1888) and Adderley's Stephen Remarx (London, 1893) were immensely popular.

s "I should not like the impression to be that 'common' meant very frequent", he explained, "You do meet with it [incest] and frequently meet with it, but not very frequently." PP, 30 (1884-5), RCHWC II, p. 177. See also the evidence of the Rev. A.T. Fryer, Rev. Robert C. Billings, Rev. George Smith and others, Ibid., pp. 65, 79, 85, 87, 95, 106, 121, 164, 191.

4 Ibid., p. 7. 
Commission discovered, difficult to prove or disprove, because quite understandably, most witnesses could produce only hearsay evidence. But in any case Mearns' pamphlet could hardly be ignored by a society which held so dearly the values of a morally upright, sober, Christian home. Thus in one of its aspects The Bitter Cry was an urgent plea for moral and spiritual elevation directed at a nation which never tired of looking to its standards of conduct. As such it directed the attention of the nation, as no other inquiry had done, to the one-roomed system becoming prevalent throughout London. Mearns' revelations were so serious that at the London Diocesan Conference following its publication, the dwellings of the poor took precedence over all religious matters and a special committee on the subject was established. The Pall Mall Gazette happily noted in its report on the Conference that people were at last beginning to acknowledge that "it is idle to talk of evangelizing or spiritualizing the masses as long as they are forced to live under conditions, which make even the most rudimentary morality impossible."1

If "outcast London" filled both churchmen and laymen with a sense of shame, and directed their energies to the gulf separating the classes, the "bitter cry" suggested to many that the gulf could be a dangerous, indeed revolutionary one. Thus guilt and fear combined to provide housing reformers with a sympathetic hearing. The new social conscience of the ' $80 \mathrm{~s}$, the new concern with the lives of the poor, was greatly stimulated by fear of social upheaval. Earlier housing reformers had played upon this fear, and Dickens, Kingsley, Shaftesbury, and Sims had all suggested that housing reform could prevent social revolution. ${ }^{2}$ Mearns himself had not stressed the revolutionary aspects of "the bitter cry", but he had made quite clear that something had to be done for the poor city dwellers before their patience ran out. His graphic description of "the thinnest crust of civilisation" that covered a brutish and immoral population naturally was alarming to a nervous public, and led to a fresh outcrop of writings mixing housing reform with predictions of impending revolution.

The London Baptist Association, for example, at a meeting held in November, 1883 , to discuss The Bitter Cry, drew the conclusion that the

1 Pall Mall Gazette, March 5, 1884. For similar statements see Rivington, appendix.

2 See Household Words, May 25, 1850, p. 199; C. Kingsley, "Great Cities and their Influence for Good and Evil", Miscellanies, Vol. II (London, 1860), p. 342; Potter, p. 556, and Sims, How the Poor Live...,p. 44. Ruth Glass makes the excellent point that the Victorian town was "the barracks of a vast working class whose lessons in the power of combination had also begun, and whose sporadic riots were portents of latent insurrection", p. 16. 


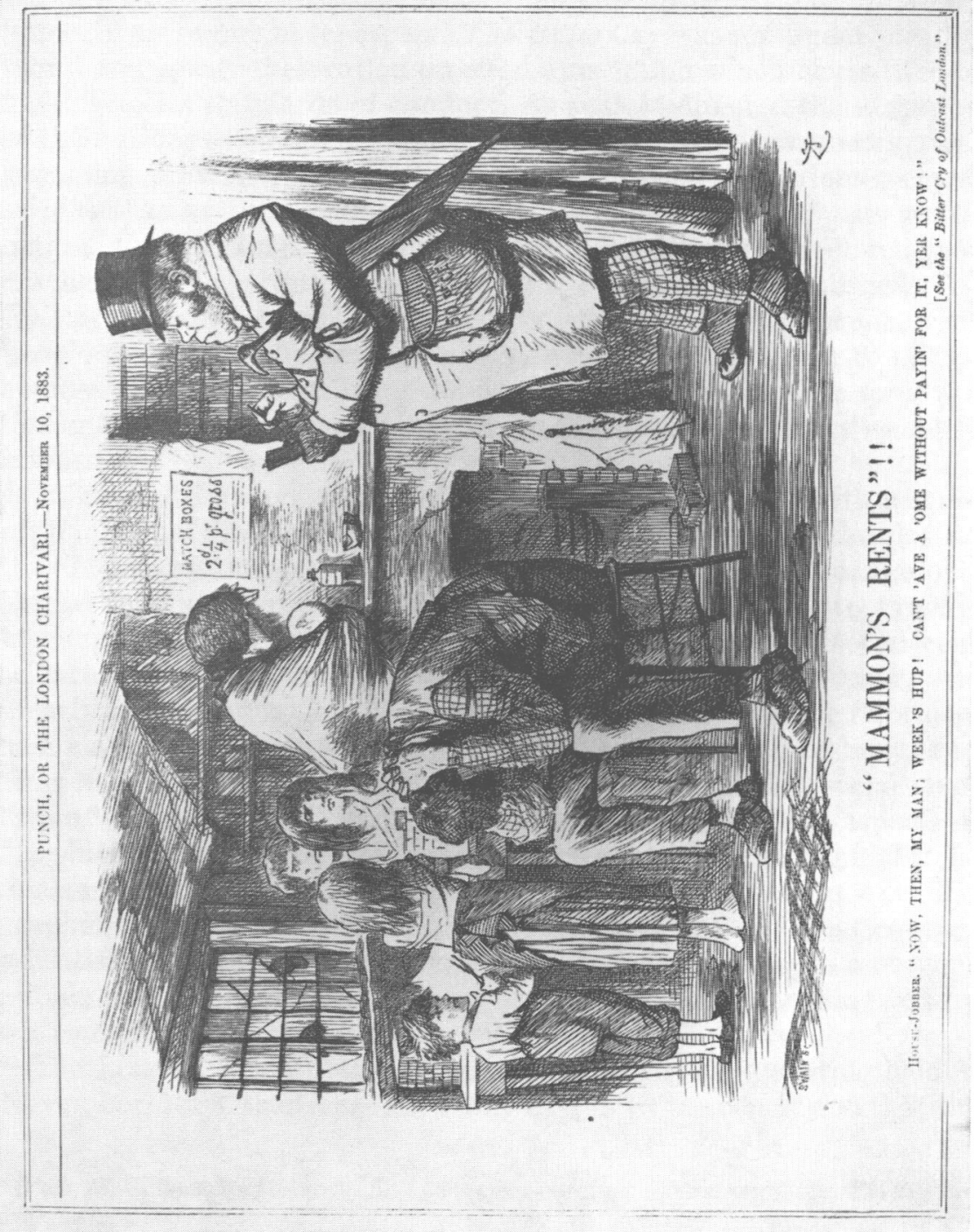


state of affairs described by Mearns "is a source of danger to the wellbeing of the community and a grave peril to the State - as a smouldering fire which accident or opportunity may at any moment fan into a flame." 1 This view was widely held. In the same month The Bitter Cry appeared readers of the Fortnightly Review were solemnly warned in an article entitled "The Housing of the Poor in Towns" that unless housing reform was accomplished revolution would occur. At the very least, it was argued, good housing was an insurance policy protecting the rich against social upheaval. ${ }^{2}$ By late 1883 and throughout 1884 the pages of the periodical press were as occupied with bad housing as a cause of possible revolution as earlier they had been with bad drainage as a cause of epidemics. Readers of the Contemporary Review were warned that East London might advance with 400,000 men if ever the "bitter cry" became a howl; Macmillan's Magazine, in an article advocating housing reform, gloomily predicted that as long as slum conditions existed, "there lurks a real danger which may involve society in an overwhelming overthrow"; the Daily News argued that no one could possibly doubt for a moment that the terrible housing conditions would sooner or later provoke poverty to make common cause against wealth; even Punch shared in the common fear, and in a poem directly inspired by The Bitter Cry entitled "Sweet Home" wondered what would finally awaken "property" to a sense of responsibility towards the slums:
"Shall it be Pestilence slow stealing hence,
To strike through callous Comfort's vain defence?
Or Misery's red revolt? or the late stir
Of harrowed feelings and indignant sense?"3

In December, 1883, after The Bitter Cry, as we shall see, inspired both the Queen and Sir Charles Dilke (the President of the Local Government Board) to pay attention to the slums, Punch imagined a conversation between them, in which Dilke is made to agree with Victoria's observation that housing legislation was the "safest mode of protecting our present constitution" and "the best, if not the only, method of

1 Daily News, November 29, 1883.

2 Fortnightly Review, XLIX (October, 1883), p. 596. The author was the infamous Frank Harris.

3 Brooke Lambert, p. 916; "London Landowners, London Improvements, and the Housing of the Poor", in: Macmillan's Magazine, pp. 8-9; Daily News, October 19, 1883; Punch, November 10, 1883, p. 225. (This was the same issue which carried the cartoon, directly occasioned by The Bitter Cry, entitled "Mammon's Rents".) See also Lancet, December 1, 1883, p. 1050. 
nipping Communism in the bud". ${ }^{1}$ So frequently was housing reform urged as a remedy for revolution, that the Saturday Review, in an article entitled "The Slum and the Cellar" protested what it termed "impolitic and unmanly" sentiments. It warned that "nothing can be weaker than to go about confessing that we are benevolent because we are in fright". ${ }^{2}$ Mearns' pamphlet, appearing at a time of increasing public violence ${ }^{3}$ thus aggravated the fear that the overcrowded rooms of the poor were breeding grounds for malcontents and revolutionaries. In an age of unemployment, of increasingly organised labour and international socialism, the political dangers of the slums could not be ignored. When Cardinal Manning asked Mearns in one of the sessions of the Royal Commission on the Housing of the Working Classes if social discontent took a political form among the more educated of the slum dwellers, he was merely expressing an anxiety about revolution or socialism (and to many they were synonymous) which was widespread and which created a public sympathetic towards advocates of housing reforms. ${ }^{4}$

Awareness of the class gulf, and the fear and guilt which it inspired, and horror and shame at the discovery of widespread immorality and indecent overcrowding among the poor help to explain why The Bitter Cry was so widely acclaimed, and why the housing reform movement in 1883 took on an urgency it had hitherto lacked. But in a golden age of social reform, teetotal advocates, Malthusians, sanitary reformers, educationalists; opponents of the vestries, municipal reformers, land reformers, critics of prostitution, evangelicals, vague humanitarians, the rich, the energetic, leisured women, and journalists, all had something to gain by becoming housing reformers. The Victorians often sought panaceas for deep-rooted social ills - naturally as housing reformers gained in energy and became more articulate and vociferous, their views could be accepted as an instant solution to several social problems. Indeed, Lord Brabazon, who espoused urban reforms because he was afraid of the "decay of bodily strength in towns" and "degeneration of the race and ... national effacement"5 argued that everyone should have an interest in the health of the city masses:

1 Punch, December 8, 1883, p. 270.

2 Saturday Review, October 27, 1883, p. 522.

3 Fear that Irish violence would spread to England was widespread at that time. The monster meetings in Hyde Park and Trafalgar Square in 1886 and 1887 soon confirmed the worst fears.

4 PP, 30 (1884-5), RCHWC II, p. 178.

- Lord Brabazon, "The Decay of Bodily Strength in Towns", in: Nineteenth Century, XXI (May, 1887), p. 674. Fear of the effect of physical deterioration upon the strength of the nation reached a climax in the investigations of the Interdepartmental Committee on Physical Deterioration (1904). 
"the working-men for their own sakes and for that of their children; military and naval men for the reputation of their country's arms; philanthropists and divines for the love of their fellow-men; employers and capitalists for the sake of improved trade; and statesmen lest they find that the Britain which they profess to govern is sinking before their eyes, borne down by no foreign foe, but undermined through physical causes which might have been avoided but for the blindness and obstinacy with which they have fixed their gaze on distant objects and questions of haute politique to the neglect of nearer and less interesting but more indispensable reforms connected with the health and physique of people of Great Britain and Ireland."1.

\section{IV}

Just as Mearns expected, The Bitter Cry was attacked by some as gross exaggeration, and the element of sensationalism in the agitation following the publication was deplored by Samuel Barnett, the Charity Organization Society, The Times, the City Press, Punch, Lancet, and, rather ironically, the Pall Mall Gazette. ${ }^{2}$ But the more general response was a widespread demand for an official government inquiry into the state of working class housing. The request for governmental committees of inquiry can usually be interpreted in two ways - either as a delaying tactic to take the steam out of an over-heated reform movement, or as

1 Lord Brabazon, Ibid., p. 676. For the attitude of the Malthusian League, see the Malthusian, No 4, May, 1879, and No 57, December, 1883. The President of the Sanitary Institute of Great Britain struck a Darwinian theme frequently heard when he stated that "In the great struggle of nations the best won, because goodness was the association of strength and healthfulness" (The Times, September 26, 1883). Brabazon's inclusion of "employers and capitalists" is most interesting. Protectionists tried to suggest that housing reforms were dependent upon the adoption of protection, which alone could boost wages (see, for example, Daily News, November 14, 1883). The author of "The Housing of the Poor in Towns" contended that "It is in the interest of all in the community that the workman should become a better instrument of production..." (Fortnightly Review, XLIX, p. 596). For an interesting observation on the connection between social reform and the fear of foreign militarism and economic competition, see O. McGregor, "Social Research and Social Policy in the Nineteenth Century", in: The British Journal of Sociology, Vol. VIII, No 2 (June, 1957).

2 The Times, November 28, 1883; Punch, December 15, 1883, p. 285; the Rev. Samuel Barnett, "Sensationalism and Social Reform", in: Nineteenth Century, XIX (February, 1886), p. 282; the City Press, May 13, 1885; H. Bosanquet, Social Work in London, 1869-1912 (London, 1914), pp. 74-5; Lancet, December 15, 1883; Pall Mall Gazette, February 15, 1889 (it attacked the "scores of would-be Zolas. A good many of them ... sang for lucre and self-advertisement."). 
the legitimate desire to learn the true nature of what is generally recognised as an intolerable situation. The latter is most applicable to the demands made in late 1883 and early 1884 . Throughout the history of the public health movement the existence of statistical evidence had been of great value to reformers, and, as John Simon's latest biographer has remarked, the Victorians "possessed a genuine belief in the dynamic power of mere information, in the inevitability with which accumulated knowledge could induce progress". ${ }^{1}$ From all sides the clamour for precise information was raised. As early as November, 1883, the Queen was petitioned, following a public meeting called to discuss The Bitter Cry, to appoint a commission of inquiry. ${ }^{2}$ In the same month the Illustrated London News wrote that although much was already known about the London poor, more information would "deepen public sympathy, and prepare the way for those drastic remedies" which would alone remove "these terrible plague spots". ${ }^{3}$ In December, Viscount Cranbrook in the pages of The Times requested a Royal Commission, and the ardent reformer and Times columnist, the Rev. Lord Sidney Godolphin Osborne, demanded a comprehensive "statistical return" of the way the working man managed his life. If the present agitation was to be more than "windbag cackle and Dodonian branglings of oratorical kettles", it was argued, there should immediately be "a complete and exhaustive Bluebook of Poverty, Misery, and Vice - not mere dryasdust tables of statistics, but earnest and elaborate reports ..."4 The following month, the Tory Quarterly Review voiced a similar demand: it complained that all existing information was based upon "mere guesses" or "generalisations from very insufficient data", and argued that "this lack of accurate knowledge of the state of London is a serious obstacle in the way of reform". It wanted to know:

"with precision, where the unhealthy dwellings are, and how many there are; what must be pulled down, and what can be repaired; how numerous the class is, that ought to be better housed; what are its sub-divisions; who are the owners of unhealthy dwellings; who are the sub-lessees and immediate holders; what rents are charged; what rents are paid; what rents ought to be paid."5

These demands for an analysis of the extent and degree of poverty in London were met in the most remarkably comprehensive manner by

1 Lambert, p. 264.

2 Daily News, November 29, 1883.

3 Illustrated London News, November 3, 1883, p. 418.

4 Ibid., December 15, 1883, p. 571.

5 "Dwellings of the Poor", in: Quarterly Review, CLVII (January, 1884), p. 148. 
Charles Booth, whose careful pioneering social investigations crammed with statistical house-by-house and street-by-street analysis were in sharp contrast to the general, often vague and impassioned sketches and descriptions that preceded his multi-volume Life and Labour of the People of London. ${ }^{1}$ This brilliant work, a landmark in urban sociological methodology, was, like the Royal Commission on the Housing of the Working Classes, which preceded it, but part of a whole complex of investigations conducted in the decade of the ' 80 s to discover the working and living conditions of the working classes. As such, its importance and significance, like that of the Royal Commission, transcends the limits of housing reform, and it must be placed within the context of a decade of unrest, agitation, and re-evaluation of the fundamental structure of society. Agricultural depression, factory working conditions, the poor law, private charities, education, workmen's trains, wages and cost of living, the sweating system, and the leasehold system, were all subjected to official investigation during the 'eighties. ${ }^{2}$ When in early 1884 Lancet wrote that the forthcoming parliamentary session would be judged "not by the mere extension of political privileges to classes that need bread .... but by the humanity of its legislation", or when in his article on "Rich Men's Dwellings", Austin wrote that "social questions are becoming the only political question about which serious persons much trouble themselves...", they were merely giving voice to the prevailing sentiment that the social, that is the working and living conditions, of the working man must be the prime political consideration of the day.

Thus it would be wrong to suggest that The Bitter Cry alone was responsible for a new empirical approach to the slums, and alone should take the credit for the great inquiries of the ' 80 s into working class housing conditions. Nothing could be more inaccurate. And yet it would be equally inaccurate to dismiss The BitterCry as but yet another of the many protest pamphlets of the period and one which, only when added to all the others to form part of a general reform agitation, takes on any value and significance. Quite the contrary, The Bitter Cry had a most direct and indeed most potent influence upon both Booth, and,

1 For Booth see T.S. and S.M.B. Simney, Charles Booth. Social Scientist (London, 1960). See also Glass, who states, "The Booth group spent their emotion far more in collecting facts and producing representative evidence, than in dismay at the sight of the facts themselves", p. 9.

2 For the inquiries of the 1880 s see Lynd, passim. Particularly important was the royal commission on agricultural depression and the select committee on sweating. The former suggested to many that urban problems would be solved only when the agricultural labourer stayed on the land. The latter pointed up the wretched condition of working class dwellings.

3 Austin, p. 463; Lancet, February 2, 1884, p. 209. 
more immediately, the decision to appoint a commission of inquiry into working class living conditions. Booth's exhaustive study was inspired directly by the desire to test the astounding facts in The Bitter Cry; thus by stimulating Booth Mearns must take the credit for inspiring the first really scientific analysis of London working class living conditions and social habits. ${ }^{1}$ Similarly, the Royal Commission on the Housing of the Working Classes, which was appointed in March, 1884 , was the direct product of the agitation which Mearns had provoked at the end of 1883 . In later years when W.T. Stead recalled The Bitter Cry he said it "caused the appointment of the Royal Commission on the Housing of the Poor, from which modern social legislation may almost be said to date."2 In the summer of 1883 , before The Bitter Cry appeared, Henry Broadhurst (who later served with distinction on the Commission), had asked in the Commons for an inquiry into working class housing, but at that date his request could be coldly dismissed by the Prime Minister, Gladstone, without causing any protest. ${ }^{3}$ Mearns' pamphlet appeared during a parliamentary recess. Parliament reassembled on the 5th February. On the 7th, Lord Salisbury, the leader of the Tories, gave notice that he would move the appointment of a Royal Commission on housing and a little over two weeks later, he rose in the Lords to do so, in a long and impassioned speech - the first, in fact, of any importance, by a party leader on the subject. Salisbury, in the course of this speech, drew attention to the "numberless pamphlets and writings during the past Recess on the subject", and stated that lately "the attention of persons of every class, of every creed and school of politics, has been turned to this question of the housing of the poor; ..."4 During the debate several references were made to the extent of the public agitation, and when Viscount Cranbrook informed his fellow peers that "a work which had created a great sensation - the book called "The Bitter Cry of Outcast London"' contained evidence of the mingling of the sexes in the sleeping quarters of the common lodging houses, he was greeted with"horrified cries of "impossible" from the outraged House. ${ }^{5}$

The agitation during the winter of 1883-4 had obviously made a great impression upon the Liberal cabinet, for when Parliament had

1 T.S. and S.M.B. Simney, pp. $65 \mathrm{ff}$.

2 Quoted in Whyte, I, p. 105. Not surprisingly Sims regarded the agitation of 1883-4 to be responsible for the appointment of the Commission. Daily News, March 13, 1884. For other pressures put upon the government to appoint a commission see, The Times, January 26, 1884, Illustrated London News, November 3, 1883.

3 Hansard, 3rd Series, CCLXXXI (1883), p. 52.

4 Ibid., 3rd Series, CCLXXXIV (1884), p. 1680.

5 Ibid., 3rd Series, CCLXXXIV (1884), p. 1704. 
closed for the recess there was absolutely no talk of a commission of inquiry into housing, yet within seventeen days of reassembling the government stated that it had already decided to issue a commission and the Prince of Wales publicly announced his acceptance of an invitation to sit upon it. ${ }^{1}$ Most important of all, The Bitter Cry shocked Queen Victoria and converted Dilke into an energetic housing reformer. Victoria was "deeply moved" by Mearns' work, and under its influence became for a brief spell almost a social reformer, and the interest of both the Prince and Princess in working class housing seems to have stemmed, in part, from it. ${ }^{2}$ As early as October 30,1883 , the Queen wrote to Gladstone from Balmoral about her distress at "all she has heard and read lately of the deplorable condition of the Homes of the Poor in our great towns". She drew Gladstone's attention to the "painfully distressing statements that have been published of the increasing misery", and she asked her Prime Minister what steps he proposed to "obtain more precise information as to the true state of affairs in these overcrowded, unhealthy, and squalid abodes". To his horror, no doubt, Gladstone now discovered that the Queen had suddenly become a housing reformer and meant to put pressure on the government while public interest was running high. She concluded her letter on an imperative note, urging, almost ordering, Gladstone to hurry. ${ }^{3}$ Gladstone, who had little interest in the subject, desperately tried to evade the Queen's demands by referring rather vaguely to recent improvements, but Victoria was not to be so easily satisfied, and she continued to question leading politicians, including Cross, Harcourt, and Dilke, about working class housing. ${ }^{4}$

Dilke's response to The Bitter Cry was as immediate as the Queen's. Acting as President of the Local Government Board he quickly sent a circular to the local authorities throughout London, summarizing existing housing legislation and the powers granted by it. ${ }^{5}$ As early as November 12, he was visiting some of the worst courts and alleys of Shoreditch in the company of the local medical officer, and he later paid visits to the worst parts of St. Luke's, Clerkenwell, St. Giles', and

1 Ibid. The Daily News announced on February 9 that there would be a royal commission on housing; on the 15 th it wrote that Dilke would serve as Chairman, and four days later it listed some of the members.

2 Roy Jenkins, Sir Charles Dilke (London, 1950), p. 173; Pall Mall Gazette, July 9,1889 . The Prince of Wales conducted his own investigation of the worst parts of St. Pancras and Holborn, and later, Soho. Ibid., February 19, 1884; July $9,1884$.

8 Dilke Papers, Vol. II, 43, 875, entry 145.

4 Elizabeth Longford, Queen Victoria. Born to Succeed (New York, 1964), pp. 462-3.

5 Lancet, January 26, 1884. 
the Strand. Through these visits Dilke learned that "outcast London" could be discovered in the West as well as the East End. ${ }^{1}$ One of the first areas Dilke inspected was Bermondsey, including Collier's Rents, which, as The Times was quick to remark, was the area described in The BitterCry. ${ }^{2}$ Dilke knew Mearns personally and remarked that he had received more assistance from Mearns than from anybody in pursuit of his inquiries into the exact state of working class London. ${ }^{3}$ Dilke won great prajse from the press for his prompt action, including the rare honour of a full page cartoon compliment from Punch entitled, significantly, "Seeing's Believing".4 Opposite the cartoon Punch published a poem entitled "The House that Capital Built", full of references to The Bitter Cry. The final stanza ends:

"And this is Punch who is glad to say That's right SIR CHARLES, you have hit on the way to tackle this problem of many phases, and track the truth through its puzzling mazes, by practical firsthand observation, with quiet skill and without sensation - say to the Statesman, worthy the name, who, holding that seeing's believing, is game to search himself in the slums and courts, to test the truth of the dread Reports, freely put forth by Pulpit and Press, that threaten attack (may it meet success!) upon the Bullion in swelling bags, gathered from hunger and dirt and rags, by the Agent, smug and content, who harries poor wretches for weekly rent, to plump the profits, fifty per cent. of the Housejobber, all unashamed by the Horrors not to be named, that haunt the Outcasts who herd in the House that Capital built. ${ }^{\text {" }}$

It is perhaps worth noticing in passing that Punch was one of the many journals whose interest in living conditions disappeared after the middle of the century and did not reappear until the winter of 1883 . Dilke's energetic inspections confirmed that housing conditions were bad throughout London, and it was clear that urgent action was needed to satisfy the public and solve the problem.

The Royal Commission on the Housing of the Working Classes which sat from March, 1884 to February, 1885 was most distinguished. Lancet was annoyed that there were no representatives of the medical

1 Illustrated London News, December 15, 1883.

2 The Times, November 16, 1883.

3 Daily News, December 12, 1883.

4 Punch, December 1, 1883, p. 259. See also Illustrated London News, November 24, 1883; and Lancet, November 17, 1883, p. 872. Obviously Dilke's personal inquiries were unusual for a President of the Local Government Board.

5 Punch, December 1, 1883, p. 258. 


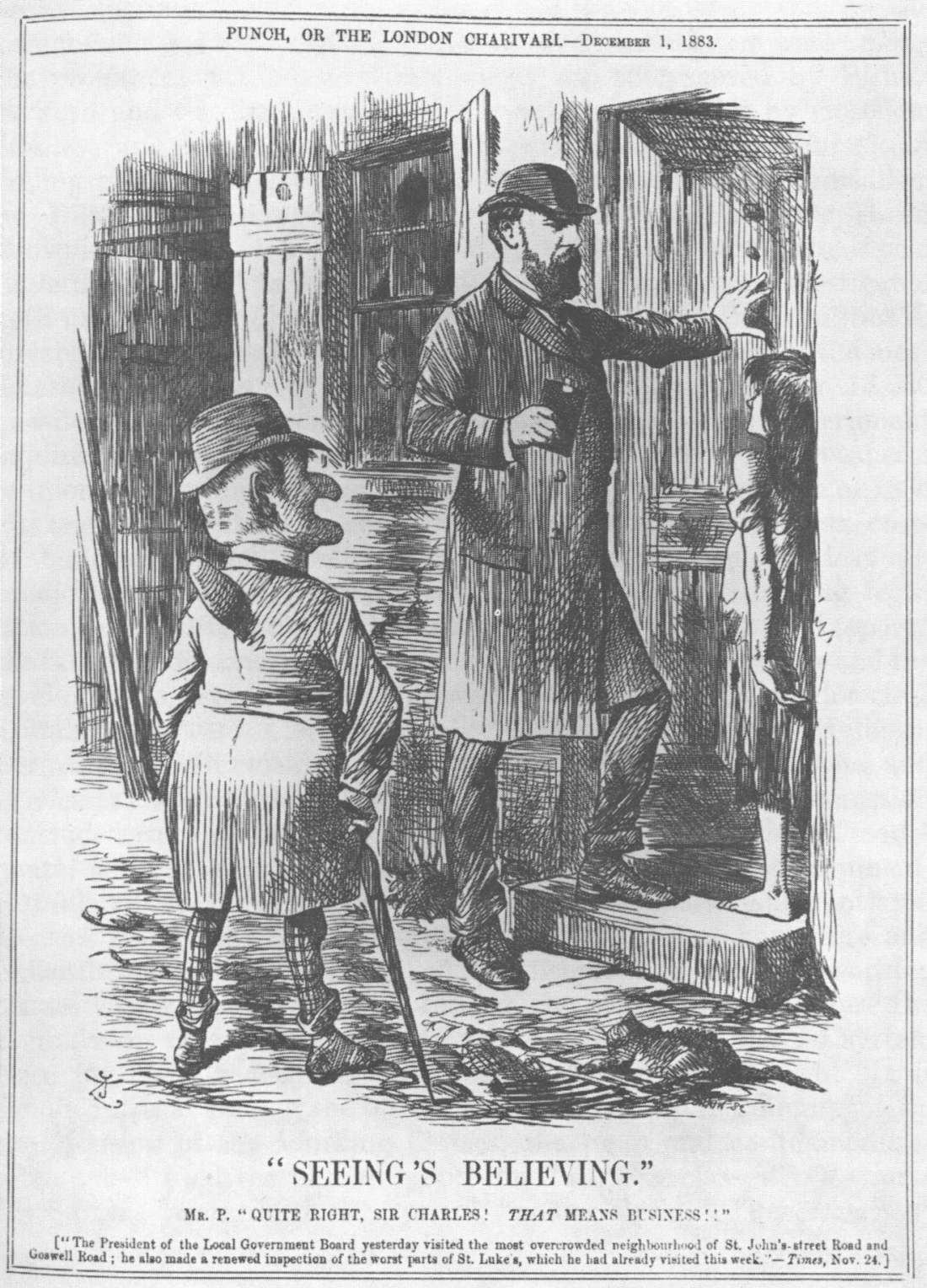


profession upon the Commission, but the absence of doctors on the Commission was not of vital importance, and medical men were among the prominent witnesses. ${ }^{1}$ The Church was represented by Bishop Bedford and Cardinal Manning; Laissez-faire principles by Goschen, Stanley, and Morley; working class radicalism by Broadhurst and Collings; experienced housing reform by Cross; aristocratic radicalism by Dilke; and ambiguous Tory Democracy by Salisbury; Lord Brownlow represented rural property; Lord Carrington, the Local Government Board in the Upper House. The Commission investigated both urban and rural housing conditions, not only in England, but in Ireland, Scotland and Wales also. It went about its work in the most determined manner: the Minutes of Evidence contain over 18,000 questions for England and Wales alone. Unlike earlier government inquiries, which concentrated upon sanitary and general health aspects or upon the workings of particular legislation, the Commission of 1884 was concerned with all aspects of the "housing question" - rents, costs of building, model dwelling companies, philanthropic endeavour, municipal enterprise, vestry activity, the efficacy of existing legislation, leases. But above all, both in its sessions, and in its final report, ${ }^{2}$ the Commission concentrated upon overcrowding and its causes and the level of rents, especially in London. Areas of London chosen for close examination were Clerkenwell, St. Luke, St. Pancras, Holborn, Bermondsey, Whitechapel, Southwark, Notting Hill, Marylebone, and to a lesser extent Chelsea, Hackney and Westminster. The Commission concluded from its investigations that existing legislation was inadequate, and that there was need for stronger municipal government. But above all the investigations of the Commission substantiated Mearns' statements concerning overcrowding. Private enterprise and philanthropic building had proved insufficient to provide the working classes with adequate housing. Indeed, the evidence given before the Commission revealed that overcrowding and the one-roomed system were far more widespread than had hitherto been thought. It is significant that though the official title was the Royal Commission on the Housing of the Working Classes, the press and contemporaries often substituted the phrase "poor" for "working classes". Of course these terms "working class", "poor", "poorer classes", "lower classes"

1 Lancet, March 1, 1884, p. 404. See also Jenkins, pp. 174-6. Many newspapers agitated for the inclusion of Octavia Hill on the commission, but like Lord Shaftesbury, the doctors, and school visitors, she proved more valuable as a witness.

2 The First Report was devoted to England and Wales, the other Reports to Ireland and Scotland. 
were freely interchangeable throughout the Victorian period, ${ }^{1}$ but in reading the popular and indeed official literature on the housing question up to and including much of 1884 , one has the distinct impression that the badly ventilated, poorly constructed and overcrowded dwellings were thought to be occupied by the very poorest only. Not until Booth's pioneering study was there a strict cost-of-living definition of poverty and an attempt to fit a geographical analysis of poverty into a scale ranging from well-paid artisans above the poverty line to unemployed labourers well beneath it. But the message to be derived from the massive but readable Minutes and the Reports of the Royal Commission, well before Booth, was clear. No longer could the descriptions of Mearns and his predecessors be dismissed as exceptions. No longer could overcrowding, and the existence of large families and more than one family in a single room be shrugged off as the inevitable plight of the "abject poor". For the Commission discovered and the press publicized, the fact that the families of the industrious, regularly employed, respectable artisans and labourers were paying far too much for far too little accommodation and were being forced by the housing shortage and high rents into the tainted physical and moral atmosphere of the one-roomed system. ${ }^{2}$ The Royal Commission stressed in its Report Shaftesbury's evidence based upon sixty years' involvement in the subject that "overcrowding has become more serious than it ever was" - an opinion "corroborated by witnesses who spoke from their own knowledge of its increase in various parts of the town". ${ }^{3}$ Even though there was nothing in the reports of the Commission to "shock landlordism to the centre", as the more radical press had hoped, ${ }^{4}$ the general significance of the Commission's findings was not missed by most of the press. The Pall Mall Gazette, with its usual perception, was correct in hailing the First Report as "epoch-making", and to read between the lines of the fairly conservative report to the

1 There was actually a parliamentary definition of "working class". "The expression 'working class' included mechanics, artizans, labourers, and others working for wages, hawkers, costermongers, persons not working for wages but working at some trade or handicraft without employing others except members of their own families, and persons, other than domestic servants, whose income in any case does not exceed an average of thirty shillings a week; and the families of any such persons who may be residing with them." Quoted in J. Calvert Spensley, "Urban Housing Problems", in: Journal of the Statistical Society of London, LXXI, Part II (March, 1918), p. 175.

2 PP, 30 (1884-5), RCHWC I, p. 20. See also below, pp. $238 f$.

3 Ibid., p. 11

4 See for example Reynolds Newspaper, May 17, 1885. Reynolds Newspaper wanted municipal buildings, let at cost, and felt, like many others, that the root of the solution lay in agrarian reforms which would keep people on the land and out of large cities. Lancet (May 23, 1885, p. 953) was disappointed in the Report. 
principal emphasis upon overcrowding underlying it. ${ }^{1}$ For the Report of the Commission suggested that it had grasped the essential fact that the "housing question" was one of supply and demand, rents and costs. Its suggestions were therefore based upon a new appreciation of the real problems. It called for a stronger central control over housing, and recommended that the workings of the Shaftesbury Acts be turned over from the local vestries to the Metropolitan Board of Works. ${ }^{2}$ In principle this was to suggest that a central municipal authority for the whole of London would one day have to be given building as well as demolition rights. ${ }^{3}$ The Pall Mall Gazette was thus not exaggerating greatly when it wrote that "there is nothing which the most advanced school of State socialists have ever dreamed of which is not to be found advocated in principle, if not pushed to its extremist application, within the four corners of the Report."4

After the recommendations of the Royal Commission there rapidly followed a series of important housing acts which firmly established the municipal government of London in the role not only of house builder but of landlord as well. In the Housing Act of 1885 the existing central municipal authority, the Metropolitan Board of Works, was given permission to build and let working class houses. ${ }^{5}$ In 1890 , following the creation in 1888 of the much more powerful London County Council, an important housing act was passed, which not only consolidated much previous legislation but which also gave the LCC considerable control in the matter of unsanitary houses over the local vestries, and permitted the LCC to build dwellings for the evicted under the Cross Acts, and to build and maintain lodging houses, aided if necessary by the power to purchase compulsorily land for the purpose. ${ }^{6}$ Under Part Three of the Act the LCC was empowered to use the rates, not merely to provide

1 Pall Mall Gazette, May 8, 1885. This was a leader, entitled, “An Epoch making Report".

2 Only the City, within the metropolis, had used the Shaftesbury Acts to build model dwellings. The vestries were notoriously apathetic to housing needs, and the move towards the central authority was designed to make the Shaftesbury Acts meaningful.

a The central authority, the Metropolitan Board of Works, did not have power, under the Torrens and Cross Acts, to build and maintain working class dwellings on the land they cleared. Usually the site was sold, below commercial value, and often after years of negotiations, to a model dwelling company. It is significant that the memorandum added to the First Report by Collings, requesting that power be given to local authorities to purchase and maintain land and dwellings, was signed by one half of the Commission.

4 Pall Mall Gazette, May 8, 1885.

5 See $n .3$ above.

6 53 \& 54, Vic. c. 70 . 
dwellings for the evicted of its slum clearance schemes, but also to compete generally with private builders. In 1900 the Council was empowered to purchase land outside the County of London for the purpose of erecting working class dwellings. It has been estimated that five years or so after the LCC decided to build outside the County, it was providing about seven per cent. of all working class housing in London - an enormous stride towards large-scale municipal socialism in the field of working class housing. ${ }^{1}$

These remarkably radical acts had as their central purpose the solution of overcrowding. The relationship between Mearns' pamphlet and this legislation is important, for The Bitter Cry excited a general concern over overcrowding and this concern, as The Times admitted, despite its "tendency to sensation" was found by the Royal Commission to be more than warranted. ${ }^{2}$ Once again, as so often before, the Victorians bowed to the necessity of passing legislation whatever the cost to general political theories and beliefs. In housing, as in other areas during the nineteenth century, laissez-faire principles were sacrificed shortly after a government inquiry officially revealed the true nature and extent of an existing abuse. That overcrowding was becoming more widespread and the demand for low cost housing too great for private enterprise to satisfy is indicated by nearly all the available evidence. Contemporaries often suggested that overcrowding and the scarcity of houses were not as bad as figures implied for two reasons. First because the working man tended to be migratory in his habits, and moved around frequently from dwelling to dwelling (often to avoid rent payments) thus giving the impression that there was a greater demand for housing than there really was; and secondly, there were, in fact, many vacant working class houses available, thus suggesting that the building industry probably was meeting demand. ${ }^{3}$ In fact it is rather difficult to get behind the empty house statistics which do exist. ${ }^{4}$ Many of the empties were of course badly located - generally the houses that went to swell the empty house figures were products of speculative building techniques (often jerry-built) in the suburbs, run up along prospective railway lines, and for a variety of reasons failing

1 Hansard, IV Series, Vol. III (1909), p. 850.

2 The Times, May 8, 1885.

3 For the mobility of labour see H. Bosanquet, "People and Homes" in: Economic Journal, X (March, 1900), and the Pall Mall Gazette, March 12, 1884. It is interesting to note that Bosanquet set out to deny the lack of rooms for the poor, but in her article she substantiated the great degree of overcrowding.

${ }^{4}$ For statistics of empty houses see E. G. Howarth and M. Wilson (eds), West Ham, A Study in Social and Industrial Problems, being the Report of the Outer London Inquiry Committee (London, 1907), passim. See also the numerous tables of house accommodation, including unoccupied houses, in LCC, London Statistics. 
to lure the working man out to them. ${ }^{1}$ One central fact controlling the supply and demand of working class houses in the nineteenth century (until the Cheap Trains Act of 1884) was the need for the working man, and especially the casually employed labourer to live near his work. The porters and dock-workers, for example, were often hired from day to day on a first come basis, and had to be within short walking distance of their work. Poorly located houses, however cheap, were of little use to these men. Thus statistics of empty houses were of more comfort to politicians who wished to remain optimistic about urban housing problems, than to the working men. ${ }^{2}$ House density figures are misleading in many respects (and not until the census of 1911 were separate room figures given for dwellings in London), but such figures as we do have suggest that the pressure of the working class population upon available and suitable housing was intense. In 1896 London's person to house density figure (all classes) was 8.02 , the highest of the century. The figure for 1891 (7.89) was the second highest recorded. ${ }^{3}$ In 1891 in Finsbury 52.4 per cent of all those living in tenements of from one to four rooms were living in overcrowded conditions. The next three most overcrowded areas of East and Central London were: Stepney (45.3), Bethnal Green (45), and Shoreditch (43.9). ${ }^{4}$ The LCC for statistical purposes considered more than two persons to each room to constitute overcrowding. By this measure, in the County of London in 1891 , over 56,000 one-roomed tenements, over 55,000 two-roomed tenements, over 24,000 three-roomed tenements and nearly 10,000 four-roomed tenements were overcrowded. Out of a total of 632,148

1 For the building process in the suburbs, see H. J. Dyos, Victorian Suburb. A Study of the Growth of Camberwell (Leicester, 1961). West Ham, for example, had 9.27 per cent. of its population living in overcrowded rooms, yet in 1905 had over 47,000 empty houses (Howarth and Wilson, p. 24). Houses built in Willesden, Hammersmith and Battersea remained unoccupied for want of cheap workmen's trains. See H. Pollins, "Transport Lines and Social Divisions", in : R. Glass et al., eds, London. Aspects of Change (Centre for Urban Studies: London, 1964), p. 43. 2 The Birmingham Corporation, for example, quoted empty house statistics after its great slum clearance scheme to suggest that it had satisfactorily re-housed the evicted, which was far from the case. For the distance from work many workmen could contemplate living, see E.J. Hobsbawm, "The Nineteenth Century London Labour Market", ibid. Hobsbawm concludes that many workmen were tied to a walking distance - three or four miles at most - from their work places.

${ }^{3}$ London County Council, London Statistics, XII (1901-2), table B, p. x.

4 See Ibid., and ibid., XXIV (1913-1914), p. 111 These figures use the LCC reckoning of overcrowding as more than two to a room. These figures should be compared to A. Sherwell, Life in West London (London, 1897), pp. 29-30. Sherwell gives the following percentages to total population overcrowded in 1894: Whitechapel (54), St. George-in-the-East (55), Clerkenwell (54), Shoreditch (49) and St. George-the-Martyr (49). 
one-to-four roomed tenements, 145,844 were considered overcrowded, and more one-roomed tenements were overcrowded than were not. ${ }^{1}$ These figures represent all London and all classes: if figures were available for just working class London and working class homes, the percentage of overcrowding would be considerably higher.

The degree of overcrowding was due to both supply and demand factors. Although building costs, with the exception of labourers' wages, remained fairly constant throughout the second half of the nineteenth century, ${ }^{2}$ the price of land in central London rose. The model dwelling companies enjoyed the double advantage of not being forced to show high profits or declare large dividends (the Peabody Trust declared a three per cent. interest on capital invested; the other dwelling companies about five) and building, as they often did, on land cleared by the Metropolitan Board of Works or the London County Council and sold to them at the cheapest rate. Yet even they found it difficult to keep costs down to a level which enabled the casually employed and the more poorly paid labourers to afford their rents. The model dwelling companies numbered among their occupants:

"charwomen, monthly nurses, basket makers, butchers, carpenters, firemen, labourers, porters, omnibus drivers, sempstresses, shoemakers, tailors, waiters, warehousemen, watch finishers, turners, staymakers, smiths, sawyers, printers, painters, laundresses, letter-carriers, artificial flower-makers, dressmakers, carmen, cabinet makers, bookbinders, and others ..."3

yet by and large it would be accurate to say that the model dwelling companies were forced by costs to charge rents that only the artisan class and better paid, regularly employed labourers could afford. Charles Booth estimated in 1887 that the "poor class" earned under 21s. per week: few model dwelling tenants earned that little. ${ }^{4}$ The demands of commerce, banking, and industry forced up the price of land in central London, but even in the suburbs, where land was very much cheaper, the rents were of a sufficiently high level to almost

1 London County Council, London Statistics, XII (1901-02), table 11, p. 117. 2 See Spensley, p. 210, and B. R. Mitchell, Abstract of British Historical Statistics (London, 1962), p. 240.

3 PP, 30 (1884-5), RCHWC II, p. 401. These were occupants of the Peabody Buildings in 1865 .

4 Charles Booth (ed.), Life and Labour of the People of London, Vol. I, Poverty (London, 1902), Pt I, p. 33. See also p. 201, n. 2 above. In addition, a close check was kept in the model dwellings on letting and sub-letting: this discouraged many working men. 
equal those in central London when the cost of transport (even inexpensive workmen's trains) is taken into account. ${ }^{1}$ There is evidence to suggest that after 1890 speculative building in the suburbs did, for a short while, supply the need for low cost housing, but to many the suburbs were an impossibility, and to others the higher cost of living there was a deterrent. ${ }^{2}$ Thus, though unfortunately there are no available figures of working class houses built, ${ }^{3}$ all the available evidence suggests that the supply of working class housing was not sufficient to meet demand.

The demand for low cost housing was aggravated by the enormous population increase of London. Between 1851 and 1881 the population of Greater London grew from 2,680,935, to 4,766,661, and in one decade alone London's population increased by over 800,000 people. ${ }^{4}$ In addition to population growth, internal migration, due to the transformation of the City of London into a non-residential financial and commercial district, and slum-clearance, street improvements, public works, and railway construction all added to dislocation, evictions, and increased pressure on existing houses. ${ }^{5}$

But essentially the problem was one of costs - of wages and rents. Both money wages and real wages rose throughout the nineteenth century. If we take 1850 as the base year with a figure of 100 for average money wages and average real wages (allowing for unemployment) in the United Kingdom, the figures for 1883 (also adjusting for un-

1 For comparative costs of rents in the centre of London and the suburbs (taking into account the cost of workmen's trains) see London County Council, London Statistics, XI (1900-1901), pp. 384ff. For rather different conclusions see Spensley, p. 195.

2 Distance from work, cost of shopping in the suburbs compared to the large markets of central London, the inability of wives to work in the suburbs, were all deterrents. See PP, 7 (1882), "Select Committee on Artizans' and Labourers' Dwellings", II, pp. 82, 85; Hansard, third series, Vol. CLXXIX (1864), pp. 1492-3.

${ }_{8}$ There are numerous statistics of house building in the nineteenth century but no accurate figures for working class houses. The annual census did not break down the figures of house building into working class and other houses. See Mitchell, p. 239; S.B. Saul, "House Building in England, 1890-1891. A Statistical Note", in: Economic History Review, 2nd Series, XV, No 1 (August, 1962); H. J. Habakkuk, "Fluctuations in House-Building in Britain and the United States in the Nineteenth Century", in: Journal of Economic History, XXII, No 2 (June, 1962). There are some figures for working class housing, but they should be used cautiously. See, for example, London County Council, Housing Development and Workmen's Fares (London, 1913), Appendix 2, pp. 16-17. 4 London County Council, London Statistics, XII (1901-2), p. x.

5 See H. J. Dyos, "Railways and Housing in Victorian London, I", in: Journal of Transport History, II, No 1 (May, 1955). See also The Report of the Dwellings Committee of the Charity Organisation Society (London, 1874). 
employment) are 151 (money wages) and 142 (real wages). ${ }^{1}$ If we restrict ourselves to the real wages of artisans in London (using 1900 as the base figure, 100) we find real wages in $1883(82.0)$ higher than at any previous time in the century. ${ }^{2}$ But these figures must be used with great caution. Contemporaries were aware that unemployment was not the problem, so much as underemployment, and there were thousands living in London whose employment was most casual and uncertain, varying greatly from week to week and day to day. ${ }^{3}$ The cold figures of rising real wages conceal the depths of poverty in London. Booth revealed in his great study that there were vast parts of London where dire poverty was the norm. In the central part of East London, 44 per cent. of the population was living at the poverty level; in the Eastern section of East London, 32 per cent., in the central part of North London, 43 per cent., in the central part of South London, 47 per cent., and in West London 25 per cent. were also living at poverty level as defined by Booth. As might be expected, these areas of poverty conformed most closely to the areas of densest overcrowding. ${ }^{4}$

The cost of clothing, food, fuel and light, and other essentials actually declined throughout the nineteenth century, so that in general the cost of living was lower in London in 1883 than at any time previously in the century. ${ }^{5}$ The great exception to falling prices was rents (it is significant that the second set of real wages quoted above do not include the cost of rents), which rose greatly during the century, and took a much larger slice out of both the partially employed labourer's and the skilled artisan's pay packet. One witness told the Royal Commission on the Housing of the Working Classes that in recent years there had occurred a fifty per cent. rise in rents of working class dwellings in his area of London, and although this example is extreme, rents were rising rapidly throughout London. ${ }^{6}$ The Royal Commission discovered that rents were certainly rising more rapidly than wages. In $18502 \mathrm{~s} .6 \mathrm{~d}$. for a single room was a usual rent, and three rooms could be obtained for five shillings or less. By 1880 five shillings for a single room and 10 s.6d. for three rooms were by no means exceptional rents in central

1 Mitchell, p. 344.

2 Rufus Tucker, "Real Wages of Artisans in London, 1729-1935", in: Journal of the American Statistical Association, XXXI (March, 1936), p. 80. This figure of 82 for 1883 should be compared to 67.2 (1873), 56.5 (1863) and 56.7 (1853).

${ }^{3}$ It is interesting in this context to note that Dyos defines a slum as representing "the presence of a market for local casual labour". Victorian Studies, XI, No 1, (September, 1967), p. 34.

4 Charles Booth, Life and Labour ... Vol. II. Poverty, pp. 25, 26, 29.

5 Tucker and Mitchell disagree somewhat, but the overall picture of steady or declining retail prices is clear.

6 PP, 30 (1884-5), RCHWC II, p. 77. 
London. ${ }^{1}$ The Pall Mall Gazette in February, 1884 conducted a special investigation of a working class area in London and concluded that "The really sensational features of the district are the high rents." Even skilled labour could afford only one room, which cost, on an average $4 \mathrm{~s}$. 9d; two rooms cost between $7 \mathrm{~s} .6 \mathrm{~d}$. and $10 \mathrm{~s}$. and were often beyond the means of even fully employed labourers. ${ }^{2}$ Charles Booth's calculation that the "poor class" earned under 21s. per week accords well with the Royal Commission's findings that over eighty-five per cent of the working class paid one-fifth of their income in rent (in the case of the "poor" this would certainly be only one room), and almost one half of the working class paid between one quarter and a half (one to three rooms). Sample budgets present a dismal picture and reveal how difficult it was for a working man to afford decent accommodation. A typical budget for six people (head of family, wife and four children - total family earnings $£ 2.3 .9 \mathrm{~d}$.) reads:

s.d.

Rent (including 2/- off arrears) . . . . . 13.0.

Bakers a/c for bread(including1/-off arrears) . . . 3.9 .

Groceries for week $\quad$. . . . . $\quad 2.6 \frac{1}{2}$

Paid for washing (in consequence of wife working at trade)

Joint of Meat (to last three days) $\quad$. . . . . $\quad 2.7 \frac{1}{2}$

Meat for remaining 4 days . . . . . 2.3

Vegetables for week $\quad$. . . . . 3.0

$1 \frac{1}{2}$ cwt. coal (at $1 / 4$ per cwt.) $\quad$. . . . . 2.0

Butter for the week $(1 \mathrm{lb}$.) $\quad$. . . . 1.0

Sundry household requisites, soap, soda, etc. . . . . $\quad 1.0$

Oil $\quad$. . . . . 8

Insurance and club money $\quad$. . . . $\quad 1.4$

Hire of machine $\quad$. . . . . 1.6

Pair of boots for child $\quad$. . . . . 2.11

Total expenditure (for six persons)

Balance of income over expenditure

1 Ibid., RCHWC I, p. 21, Spensley, p. 195. Of course there were thousands of casually employed labourers who managed to find cheaper accommodation in rooms in cellars and in sub-standard houses for $2 / 6 \mathrm{~d}$. or $3 /-$ per week. Dwellings in the East End tended to be cheaper than in other working class districts. Unfortunately building codes and sanitation acts tended to push up rents.

2 Pall Mall Gazette, February 5, 1884.

sherwell, p. 112. Later the same family, when the head of the household was out of work, cut its weekly budget to $8 \mathrm{~s} .9 \frac{1}{2} \mathrm{~d}$. 
This particular budget does not include alcoholic drinks, nor does it include clothing (other than boots for one child) or items such as bedding and curtains, that could add to the permanent comfort of the dwelling. The labourer, in choosing to have adequate space for his family of six has cut his budget very fine, and when, as often happened, his wages fell below a pound, he was in a perilous position.

Rents were thus a great exception to the falling cost of living. In the spring of 1884 it was pointed out in Parliament that

"Since 1844 wages had risen, the taxes in necessaries had been lowered, and the ability of working men to obtain better accommodation had increased. But while that ability had increased, the rents of houses had also risen. Since 1844 house rent had increased by 150 per cent., and consequently, while the condition of the working classes had improved in all other respects, the state of their dwellings had not undergone a corresponding improvement."1

Torrens, who had spent over a decade fighting for better houses for the working man thought in 1879 that the situation had become completely hopeless. ${ }^{2}$ Shaftesbury commented a few years later that "the population were overcrowded before, but now they have become overcrowded to an extent which I have never known", ${ }^{3}$ an opinion with which Dilke, from his personal investigations, agreed. ${ }^{4}$

After The Bitter Cry and the Royal Commission on the Housing of the Working Classes revealed the vast extent of overcrowding in the working class districts of London there occurred a sharp loss of faith in private enterprise, and a critical re-examination of the housing question in terms of costs, rents, wages, and family budgets. Simon, for example, though he strongly disagreed with any government interference that would sap the spirit of self-help and self-reliance, after a life devoted to sanitary and housing reform, concluded his English Sanitary Institutions on a purely socio-economic note, which amounted in fact to a critical re-evaluation of the entire social system: "... how the house-accommodation of the poorer labouring classes may be rendered such as humane persons would wish it to be", he wrote, was in large part a question of "how far poverty can be turned into non-poverty, how far the poor can

1 Quoted in the Pall Mall Gazette, March 5, 1884.

2 Torrens, p. 542.

3 PP, 30 (1884-5), RCHWC II, p. 2.

4 Pall Mall Gazette, February 19, 1884. 
be made less poor". ${ }^{1}$ The Royal Commission's discovery of high rents and widespread overcrowding, and Booth's study of poverty, with its disturbing revelations of the large numbers living below the poverty line, clearly suggested that however actively sanitary laws were enforced by local authorities, however strictly building codes were enforced, however rigidly one enforced laws against overcrowding and the occupation of cellars and unsanitary houses, the housing question would only grow in intensity unless poverty could be eradicated. This meant, as Simon clearly realised one or both of two new approaches: wages would have to be raised, and the cost of housing had to be lowered. Simon wrote:

"Again and again, since the question of the Dwellings of the Poor has been under discussion, the inseparability of that question from various other questions regarding Poverty has become manifest; and the discussion, in its progress, has more and more compelled thought on Poverty in general, with reference to all its conditions and circumstances, domestic and industrial. The smallness of earning-power in the lowest paid branches of industry, as compared with the necessary costs of wholesome and decent living, has of course always been the main fact [in fact this was not the case: few men saw the problem as clearly as Simon]; and the possibility of rendering that ratio less unfavourable to the poorer workers, either by cheapening their costs of life, or by bettering their conditions of employment has, in a variety of forms, been the essential problem of the study."2

The "housing question" thus added to the general social unrest in the 1880 s and the demand in the last decades of the century for a reexamination of the condition of the poor in general. More immediately it led to a growing disenchantment with laissez-faire private enterprise and a growing acceptance of the need for government participation beyond the negative role of demolition of slumlands. After the Royal Commission's report, there was increased acceptance of the idea that soon the government must provide what costs made it impossible for the private builder to provide. Lord Salisbury, who had urged the appointment of a Royal Commission, and who rather surprisingly emerged in late 1883 and 1884 as the most articulate parlimentary speaker on the housing question, was the first politician of note to grasp the essential fact that the housing question was basically the

1 J. Simon, English Sanitary Institutions (London, 1890), p. 444.

2 Ibid., p. 434. The Times (November 26, 1883) considered that "the housing of the great mass of workers in London, is a question, we say, of wages ...." 
problem of overcrowding, and in thoughtful well-planned speeches Salisbury tried to impress this fact upon Parliament. ${ }^{1}$ The provision of houses to combat overcrowding, he stated, "is really the gist and kernel of the whole matter. That is the difficulty we have to meet. Are large building operations requisite; and, if requisite, where are they to be carried on, and at whose cost."2 After the Royal Commission had presented its report, Salisbury continued to stress in Parliament that while sanitary evils were being solved, "The more our prosperity increases, the more there is the danger that unless remedial measures are taken, the evils of overcrowding will also increase." 3 Salisbury's emphasis upon the provision of lodgings was a crucial one, and his question concerning who was to pay for the building raised an ideologically dangerous issue. In both his speeches in Parliament and in an article in the National Review, entitled 'Labourers' and Artisans' Dwellings" which raised great alarm among conservative elements in the country, ${ }^{4}$ Salisbury challenged the inviolability of laissez-faire. "There are no absolute truths or principles in politics", he stated. Such an opinion could be viewed as an affirmation of the traditional pragmatism of the English political mind, but, coming at the height of the housing agitation, and at a time when Morris, Marx, Hyndman, and the Fabians were all challenging Whiggish notions of individualism, this statement of ideological flexibility appeared to mark a new departure. ${ }^{6}$ Later, in his speech in $\mathbf{1 8 8 5}$ proposing the Housing Bill which grew out of the Commission's recommendation, ${ }^{7}$ Salisbury defended

1 Hansard, 3rd Series, CCLXXXIV (1884), p. 1681, and ibid., 3rd Series, CCXCIX (1885), p. 891. I discuss the role of Salisbury at greater length in the introduction to a reprint of The Bitter Cry and other housing tracts, to be published by Leicester University Press next year.

2 Hansard, 3rd Series, CCLXXXIV (1884), p. 1687.

3 Ibid., 3rd Series, CCXCIX (1885), p. 891.

4 Lord Salisbury, "Labourers' and Artisans' Dwellings", in : National Review, II (November, 1883). Salisbury had made several speeches on working class housing conditions before The Bitter Cry appeared, and his National Review article was probably planned before Mearns' pamphlet came out. In his article Salisbury advocated government loans at low rate of interest to builders of workmen's lodgings - not a radical suggestion, but one which, at the time, led to great fear among conservative elements that their leader was deserting the market economy and flirting with socialism. For the reaction to Salisbury's article, see Pall Mall Gazette, October 25, 1883.

5 Hansard, 3rd Series, Vol. CCLXXXIV (1884), p. 1689.

- The Fabians and the Democratic Federation placed housing high on their list of reforms, although they did not start campaigning energetically for reform until after 1883 .

7 Actually the Commission was far from agreed that the 1885 Act stemmed from their recommendations. Both Stanley and Broadhurst disliked the Act. Ibid., 3rd Series, CCXCIX (1885), pp. 1593, 1607. 
himself against the charge of socialism, not by denouncing socialism, but by asking for a clearer definition of it. ${ }^{1}$ Salisbury's parliamentary leadership of the housing reform movement was in part a reaction to the recent exposés and general agitation, ${ }^{2}$ and both his reaction, and the agitation itself greatly alarmed Lord Wemyss, the bitter opponent of creeping socialism and state interference in matters best left to private enterprise. ${ }^{3}$ Wemyss feared that the recent treatment of housing would drive the government towards espousing state-built and state-run subsidized housing for the working classes. In 1855 Wemyss told his fellow peers that "He hoped it would not go forth, no matter at whose cost these things should be done, that the State was going to build houses for the working people, the artizans, or the poor. He could conceive nothing which would be more prejudicial than that, because if they began on this system, where were they to stop? If they built houses, would they furnish them? Would they put fire in the grate or food in the cupboard? And, if not, on this principle, why not?" Wemyss sadly quoted a contemporary prediction that "the scheme of State Socialism which in England during the next few years is likely to assume most importance is the erection of improved dwellings for the poor by funds supplied either from Imperial or local taxation." 4 Wemyss and his Liberty and Property Defence League were not alone in fearing that the current agitation would carry the government too far. Lord Shaftesbury, for example, reported that "There is a loud cry from many quarters for the Government of the country to undertake this mighty question [of house building]; and anyone who sets himself against such an opinion", he complained, "is likely to incur much rebuke and condemnation." 5

The Royal Commission by discovering that the revelations of Mearns and others were not exaggerated destroyed many fond beliefs in current

1 Ibid., 3rd Series, CCC (1885), pp. 651-654.

2 But only in part. He seems to have been genuinely concerned with urban conditions, and there is little substance in the charge of Chamberlain and other critics that he was merely posing as the champion of Tory Democracy and trying to "dish" the Whigs.

3 For the League's views see Ibid., 3rd Series, CCLXXXIV (1884), pp. $170 \mathrm{ff}$.

4 Ibid., p. 1703. Wemyss was quoting from H. Fawcett's, State Socialism and the Nationalisation of Land (London, 1883). Fawcett voiced the opinion that there was the world of difference between state interference in strictly sanitary and health matters, and state interference in house building. The arguments used by opponents of municipal housing may be summarized: it would discourage private builders; it would destroy self-reliance and "character"; it would attract people into the towns and thus aggravate the problem; it would lead to socialism. 5 Lord Shaftesbury, "The Mischief of State Aid", in O. Hill et al., "Common Sense and the Dwellings of the Poor", in: Nineteenth Century, XIV (December, 1883), p. 934. 
cures - Octavia Hill, model dwelling companies, private enterprise, the suburbs - for the housing crisis. After its Report, attacks upon what the Saturday Review called the "complacent impotence of laissez-faire"1 greatly increased. "Private enterprise has failed ignominiously to keep pace with the demand for dwellings. The municipality must make up the leeway", cried one reformer. What was the result of private enterprise if not "rash speculation, jerrybuilding, property sweating, slumdom, and the woeful want of housing accommodation ...."2 One witness before the Royal Commission anticipated a growing sentiment when he said, "it is totally impossible that private enterprise, philanthropy, and charity can ever keep pace with the present demands; and those involved in the rapid increase of population", and he added "... what the individual cannot do the State municipality must seek to accomplish."3 The Daily News, a few weeks after Mearns' pamphlet appeared, succinctly stated, that "it ought to be clear to everybody by this time that mere private benevolence and energy can no more deal with the difficulty than private benevolence and energy could man our fleet or supply a police for our cities." ${ }^{4}$ Lancet, who considered that Lord Salisbury's views, "coinciding with the 'Bitter Cry of the Outcast Poor of London" " had "altered the whole tenour of political controversy", 5 responded to The Bitter Cry and the agitation it aroused by stating that "Economic laws are all very well; but the honest hungry must be fed; the honest naked must be clad; and the State must feel itself responsible to some extent for the housing of the decent poor", and it added "the days are gone by when the State was understood to be nothing else than a taxing, law-making machine". ${ }^{6}$

The widespread awareness of the great problem of overcrowding thus proved to be another nail hammered into the coffin of laissezfaire. The connection between Mearns' pamphlet and the legislation enabling the central municipal authority to build and own blocks of dwellings for the working classes is important. The Bitter Cry of Outcast London drew the attention of the nation to overcrowding and to a state of affairs where, as The Times remarked, a respectable London artisan "was faced with the choice either of spending half his wages on a couple of wretched rooms, or of living like a pig in a sty". " Overcrowding,

1 Saturday Review, October 27, 1883, p. 521.

2 G. Haw, The Englishman's Castle (London, 1906), pp. 48-9. See also Pall Mall Gazette, October 17, 1883.

3 PP, 30 (1884-5), RCHWC II, p. 475.

4 Daily News, October 27, 1883.

5 Lancet, December 15, 1883.

6 Ibid., November 17, 1883.

7 The Times, January 9, 1884. 
as Salisbury and others clearly saw, required positive acts of building and building at rents the poor could afford. Certainly not all reformers, perhaps not Mearns himself, would have wanted to see a central authority with the character, drive, and enterprise of the London County Council energetically enter the field of house ownership and so forcefully compete with the private builder. But as one journal commented, in reviewing the work of the Royal Commission, "The greater the desire to find an effectual remedy [for overcrowding], the greater the risk of accepting a principle which, on the face of it, seems to commit the State to socialism...." The Bitter Cry stressed the crucial aspect of the housing question, stirred the conscience of the nation, and added to its fear of social unrest. In so doing, it created an atmosphere favourable to a more positive approach to the housing question. Within a decade or so of its appearance, the age of subsidized housing and the council flat had arrived, and municipal socialism had touched even the Englishman's castle.

1 Lancet, May 23, 1885. See also the reaction of the Economist, quoted in Lynd pp. 149-150, and the Daily News, December 10, 1883. 